\title{
Exploring the transformative potential of urban food
}

\author{
Hebinck, A. ${ }^{1, \#, *}$, O. Selomane ${ }^{2, *, \#}$, E. Veen ${ }^{3}$, A. de Vrieze ${ }^{3}$, S. Hasnain ${ }^{4}$, M. Sellberg ${ }^{5}$, L. \\ Sovova ${ }^{3}, K$. Thompson ${ }^{6}, J$. Vervoort ${ }^{7}$ and A. Wood ${ }^{5}$. \\ ${ }^{1}$ DRIFT, Erasmus University Rotterdam, the Netherlands \\ ${ }^{2}$ Centre for Sustainability Transitions, Stellenbosch University, South Africa \\ ${ }^{3}$ Rural Sociology Group, Wageningen University, the Netherlands \\ ${ }^{4}$ Environmental Change Institute, University of Oxford, United Kingdom \\ ${ }^{5}$ Stockholm Resilience Centre, Stockholm University, Sweden \\ ${ }^{6}$ Faculty of Geosciences, Utrecht University, the Netherlands \\ ${ }^{7}$ Copernicus Institute for Sustainable Development, Utrecht University, the Netherlands \\ *Corresponding authors: hebinck@drift.eur.nl; odirilwes@sun.ac.za \\ \# These authors have contributed equally to this paper
}

\begin{abstract}
Urban food is a key lever for transformative change towards sustainability. While research reporting on the urban food practices in support of sustainability is increasing, the link towards transformative potential is lacking. This is because research on urban food is often place-based and contextual. This limits the applicability of insights to large-scale sustainability transformations. This paper develops a framework to synthesise insights from urban food research across multiple disciplines and explores its links to transformations research. We have developed a framework of signposts for transformative change based on processes and outcomes that are considered key for sustainable (urban) food transformations. Secondly, we classify diverse urban food practices to elevate them beyond their local, place-based contexts. We find that urban food practices carry a lot of potential to facilitate sustainability transformations. Based on that analysis, we provide insights on how urban food research can further contribute to harnessing the transformative potential of urban food practices for actionable purposes.
\end{abstract}

\section{Urban food as a site for transformation}

Urban food is regarded as a promising lever for transformative change towards sustainability (Ilieva, 2017; Moragues-Faus and Carroll, 2018; Johannes S.C. C. Wiskerke, 2015). There are two main reasons for this. First, cities are considered hotbeds for alternative practices and experimentation (Gernert et al., 2018; Torrens et al., 2019), which are vital to address the urgent sustainability challenges cities face (Elmqvist et al., 2019). Second, food links to diverse domains such as ecological, political, social, health, and economic systems (Caron et al., 2018; Hebinck et al., 2021). Acknowledging this potential, a shift towards considering urban food practice for the design of sustainable cities is visible in both research and policy (Haysom, 2015; Jarosz, 2008; Marsden, 2013; Matacena, 2016; Pothukuchi and Kaufman, 1999).

The field of urban food research itself is still emergent. Initially food was considered mostly an agricultural and 'rural affair', and not an urban issue (Sonnino, 2009). This thinking has shifted since the seminal work by Pothukuchi and Kaufman (1999), who highlighted how urban food had the potential to increase quality of urban life across diverse domains. This was the start of a turn towards consideration of food as something that connects the urban and rural (Sonnino, 2009) and as nested in a wider system (Wiskerke and Viljoen., 2012). This development sparked interest in urban food across various disciplinary communities, leading to a proliferation of research with diverse focal points in urban food, such as planning (Horst et al., 2017; Morgan, 2013), policy making (Moragues-Faus and Marsden, 2017; Sibbing et al., 2019), diverse farming practices (Renting et al., 2003), and social justice (Sbicca and Myers, 2017). While this was first aimed at better understanding and documenting the rise of these 
food practices (Levkoe, 2011; Renting et al., 2003), more recently studies explore how alternative urban food practices can be used to leverage cities towards sustainability in multiple ways (Matacena, 2016; Vieira et al., 2018).

Urban food practices encompass activities that are directly related to food such as growing, serving, designing policies for and about food, and other activities that take place in urban food systems (Kasper et al., 2017; Vieira et al., 2018). While the research is beginning to better understand urban food practices, evaluation of their potential for transformation is still done at the individual case level (see list 1 in the appendix for examples). Looking at single initiatives makes it difficult to evaluate the contribution of alternative urban food practices to large-scale systematic change (Loorbach et al., 2017; Moore et al., 2014; Scoones et al., 2020) and to distil broader insights for sustainability governance. How urban food practices can be leveraged for sustainability governance has yet to be demonstrated (Forssell and Lankoski, 2014; Matacena, 2016).

The aim of this paper is to review literature on urban food for transformative change potential. We present a framework to assess transformative potential based on recent literature on transformative change. We use the metaphor of signposts towards transformation (rather than realised transformative change) as possible indicators for a process towards transformative change (See the appendix for a Glossary). These signposts include processes and outcomes that are considered essential for transformative change within food systems, which we pool from an assortment of urban food literature. Second, to make better sense of the diversity we cluster the urban food literature into broad categories of practices, to elevate the findings on signposts beyond single cases. Finally, we elaborate how our findings relate to the emergent field of urban food and discuss avenues for future research.

\section{Signalling transformative change in urban food}

Transformations research is a fast-growing field and is characterised by multi-disciplinary influences, incorporating insights from diverse research communities including socialecological systems, transitions, political ecology, and earth system governance (Patterson et al., 2017). Transformations are broadly understood as 'fundamental change' that affects the structures, functioning, and interrelations of a given system (Blythe et al., 2018; Feola, 2015; Hebinck et al., 2018). Different schools of thought have various understandings of how such fundamental change happens. For example, transformation can be sparked by abrupt changes that present tipping points towards fundamentally new systems (David Tàbara et al., 2018; Kopp et al., 2016; Rocha et al., 2015). Transformative change can also occur through the accumulation of small wins which add up incrementally to a larger shift (Termeer and Metze, 2019), or it can be brought about by alternative 'niche' practices that manage to overthrow the dominance of mainstream 'regime' practices and give shape to a new system (Loorbach et al., 2017; Sharpe et al., 2016). Others build on the diversity of existing, positive, and novel ways forward as a way to 'sustain and amplify' existing initiatives towards transformation (Bennett et al., 2016).

The main objective of transformations research is to better understand, indicate, and reflect on processes of change that facilitate radical system change. Research on transformation initially focussed on indicating the need for transformation (Leach et al., 2012; O'Brien, 2012) and unpacking the notion of transformative change (Feola, 2015; Moore et al., 2014; Shove, 2010; Wiek et al., 2012). Increasingly, this research has become more actionable by identifying key actors and activities for social-ecological transformation (Chapin et al., 2011; Pereira et al., $2019 b$ ), setting out governance modes that further transformation at diverse scales (Biermann 
et al., 2012; Wolfram et al., 2019b), and imagines what transformations could entail (Galafassi et al., 2018; Hebinck et al., 2018). There is also work that is more critical of the concept, mainly exploring discursive and political use of the notion of transformation (Blythe et al., 2018; Feola and Jaworska, 2018; Patterson et al., 2017).

Attempts to uncover more specific leverage points and capacities needed to support urban transformation (Hölscher et al., 2019; McCormick et al., 2013), have been complicated by the temporal and future-oriented nature of transformations (Blythe et al., 2018). As such, much of the research on transformative change, explores what processes and practices may contribute to outcomes associated with or can become a starting point for transformation (Loorbach et al., 2020; Moore et al., 2014; Pereira et al., 2019b; Scoones et al., 2020). The notion of "pockets of the future in the present" (Bennett et al., 2016) is built on a similar premise that while it is impossible to know beforehand that something will be transformative, some practices that exist today have the potential to grow to become dominant in the future. Depending on the context, these practices can then 'grow' through various amplification processes: scaling up, scaling out, scaling deep, replicating, spreading, stabilizing, and so on (Lam et al., 2020; Loorbach et al., 2020; von Wirth et al., 2019). With this in mind, in this paper we look at characteristics (specifically processes and outcomes) that are considered to have potential to make a practice transformative, without claiming that such a practice is inherently transformative. Transformative change can thus be defined based on, or implied as a result of, the processes and outcomes which are expected to produce it, rather than precisely assessing the change itself.

\section{Methodology}

We first establish a framework to assess transformative change through potential, rather than focussing on realised change (Table 1). Second, we review literature that reports on urban food, focusing on empirical case studies, excluding all conceptual papers, as well as those not meeting our criteria (Figure 1). To make sense of the diversity of practices from the reviewed literature, we clustered urban food practices into six broad types (Table 2). We then use the framework we developed on transformative change and the clusters of urban food practices to determine the potential for transformative change in these urban food practices.

\section{Operationalising transformative change}

To overcome the temporal issue associated with transformations research, we start from the premise by Bennett et al. (2016) which sees existing initiatives as pockets of the future with potential for transformation. In order to understand the transformative change in urban food, we need to distil the processes and outcomes that may act as signposts to food system transformation. We take these processes and outcomes to indicate an urban food practice's transformative potential. We base this on how research envisions transformation of (urban) food systems to sustainability (García-sempere et al., 2018; Gordon et al., 2017; Hebinck et al., 2021; Horst et al., 2017; IPES Food, 2017, 2015; Kasper et al., 2017; Moragues-Faus and Morgan, 2015; Johannes S.C. C Wiskerke, 2015). Based on this reading, we synthesised a set of food system processes and outcomes (see table 1), that are generally considered signposts for sustainability transformations in food systems. 
Table 1. Food system processes and outcomes that are signposts to sustainable food system transformations

\begin{tabular}{|c|c|c|}
\hline Transformative processes & Description & Sources \\
\hline $\begin{array}{l}\text { Adoption of a city-region } \\
\text { perspective }\end{array}$ & $\begin{array}{l}\text { Including the hinterlands as part of the urban } \\
\text { food system }\end{array}$ & $\begin{array}{l}\text { Wiskerke 2015; Garcia-Sempere } \\
\text { et al. 2018; }\end{array}$ \\
\hline Creation of spatial synergies & Linking different policy objectives & $\begin{array}{l}\text { Wiskerke 2015; IPES-Food 2017; } \\
\text { Horst et al. } 2017\end{array}$ \\
\hline Influencing consumer decisions & $\begin{array}{l}\text { Raising awareness on food; sustainable nudging } \\
\text { or marketing }\end{array}$ & Gordon et al. 2017; \\
\hline Mobilisation of key actors & $\begin{array}{l}\text { Targeting several influential actors to accelerate } \\
\text { change }\end{array}$ & $\begin{array}{l}\text { Gordon et al. 2017; Österblom et } \\
\text { al. } 2015\end{array}$ \\
\hline $\begin{array}{l}\text { Reclaiming or recreating urban } \\
\text { space }\end{array}$ & $\begin{array}{l}\text { Repurposing of space for common or } \\
\text { community use; acts of resistance }\end{array}$ & Horst et al. 2017 \\
\hline Strategic planning for the future & $\begin{array}{l}\text { The use of foresight or forward-looking } \\
\text { approaches }\end{array}$ & $\begin{array}{l}\text { Zurek et al. 2018; Rutten et al. } \\
\text { 2018; }\end{array}$ \\
\hline Taking an integrated approach & Combination of multiple food system domains & $\begin{array}{l}\text { Zurek et al. 2018; Wiskerke } \\
\text { 2015; }\end{array}$ \\
\hline Using participatory approaches & $\begin{array}{l}\text { The use of multiple relevant stakeholders to } \\
\text { design, plan or develop within urban food } \\
\text { systems }\end{array}$ & $\begin{array}{l}\text { IPES-food 2015; Horst et al. } \\
\text { 2017; Zurek et al. 2018; Garcia- } \\
\text { Sempere et al. 2018; }\end{array}$ \\
\hline Transformative outcomes & Description & Sources \\
\hline Changed diets & $\begin{array}{l}\text { Changing consumption patterns towards more } \\
\text { sustainable and healthier diets }\end{array}$ & $\begin{array}{l}\text { Gordon et al. 2017; Zurek et } \\
\text { al. } 2018\end{array}$ \\
\hline Connected flows of resources & Efficient or circular use of resources & $\begin{array}{l}\text { Wiskerke 2015; IPES-food } \\
\text { 2016; Gordon et al. } 2017\end{array}$ \\
\hline Enhanced transparency & $\begin{array}{l}\text { Between producers and consumers to provide } \\
\text { context and information about the food system }\end{array}$ & $\begin{array}{l}\text { Gordon et al. 2017; Garcia- } \\
\text { Sempere et al. 2018; }\end{array}$ \\
\hline $\begin{array}{l}\text { Established food governance } \\
\text { arrangements }\end{array}$ & $\begin{array}{l}\text { Establishment of a coalition, network with a } \\
\text { common vision or strategy; the development of } \\
\text { policy for food }\end{array}$ & $\begin{array}{l}\text { Wiskerke 2015; Moragues- } \\
\text { Faus and Morgan 2015; IPES- } \\
\text { food } 2017\end{array}$ \\
\hline Greened urban spaces & To improve liveability of the urban domain & Wiskerke 2015; \\
\hline Improved food quality & $\begin{array}{l}\text { Provisioning of healthy and environmentally } \\
\text { friendly food }\end{array}$ & $\begin{array}{l}\text { Lang 2009; Gordon et al. } \\
\text { 2017; }\end{array}$ \\
\hline Increased connection to nature & $\begin{array}{l}\text { Reconnection of people to food and nature; } \\
\text { improving stewardship of the biosphere }\end{array}$ & $\begin{array}{l}\text { Gordon et al. 2017; Garcia- } \\
\text { Sempere et al. 2018; }\end{array}$ \\
\hline Increased ecological resilience & $\begin{array}{l}\text { Of production systems and the biosphere; } \\
\text { strengthening (agro-) biodiversity and multi- } \\
\text { functionality in food production }\end{array}$ & $\begin{array}{l}\text { IPES Food 2016; Gordon et } \\
\text { al. 2017; Garcia-Sempere et } \\
\text { al. 2018; }\end{array}$ \\
\hline $\begin{array}{l}\text { Increased economic } \\
\text { opportunities }\end{array}$ & $\begin{array}{l}\text { Ensuring a fair and thriving economy that } \\
\text { benefits all }\end{array}$ & $\begin{array}{l}\text { Zurek et al. 2018; Garcia- } \\
\text { Sempere et al. 2018; }\end{array}$ \\
\hline $\begin{array}{l}\text { Increased equity in the food } \\
\text { chain }\end{array}$ & $\begin{array}{l}\text { Ensuring fair and just treatment of actors in the } \\
\text { food system }\end{array}$ & $\begin{array}{l}\text { Zurek et al. 2018; Garcia- } \\
\text { Sempere et al. 2018; }\end{array}$ \\
\hline Increased self-sufficiency & $\begin{array}{l}\text { Decreasing dependency on import-products; } \\
\text { increasing the ability to supply one's own food }\end{array}$ & Kasper et al. 2017; \\
\hline Increased social resilience & $\begin{array}{l}\text { Contributing to social cohesion or strengthening } \\
\text { a community }\end{array}$ & $\begin{array}{l}\text { Moragues-faus and Morgan } \\
\text { 2015; Horst et al. } 2017\end{array}$ \\
\hline
\end{tabular}

We use this framework to assess how existing urban food practices reflect these outcomes and processes, or signposts for future urban food transformation. While we consider this useful for indicating what practices hold potential and which are worth supporting or strengthening, we do not consider this a guarantee for radical and systemic change. This depends on how these alternative urban food practices will interact and co-evolve over time.

\section{Systematic review}

The aim of the systematic literature review was to understand the degree to which urban food practices are reported as leading to transformative change. We used an iterative process to identify keywords and establish search terms able to capture publications of interest (see appendix table 1). Boolean operators were used to filter for publications that focused on cases 
of alternative food practices in the urban domain specifically, while wildcards (i.e. *) were added to capture varied use of terminology. Moreover, the search string included a proximity operator (i.e. w/1) between the keywords "urban OR city OR town" and "food OR agriculture OR garden* OR farm*". The search was able to capture a broad range of urban food practices, such as: urban food policy; urban school food; city farmers market; and urban food justice. To capture change aspects towards sustainability, we included "sustainab* OR resilien* OR transit* OR transform*" and to capture in empirical cases, we included "case OR project* OR initiative $^{*}$ OR organisation* ${ }^{*}$ OR enterprise*".

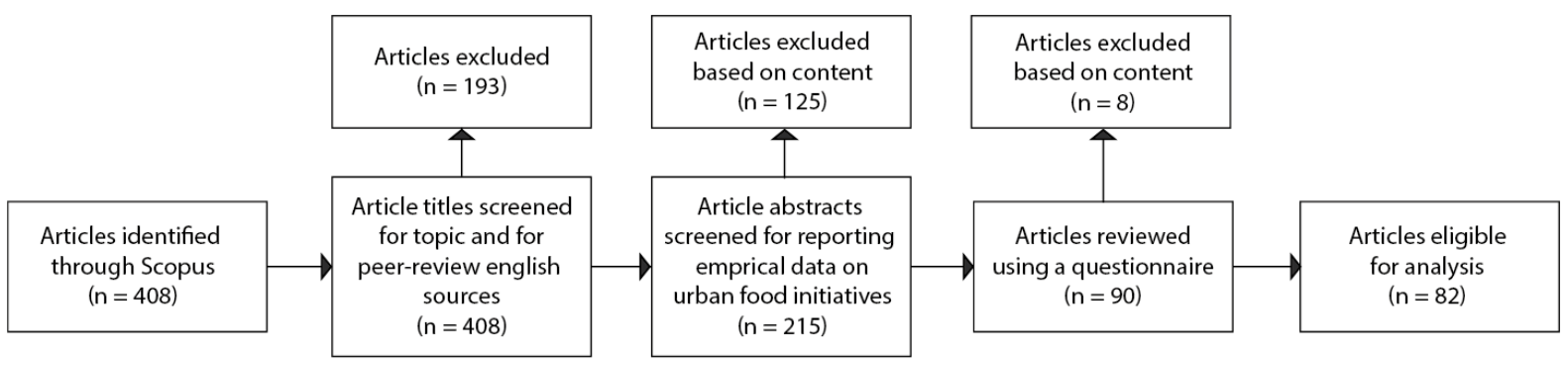

Figure 1. Selection process of literature eligible for analysis

The search was conducted on 21 June 2018 in Scopus, and limited to abstract, title and keywords and to English only articles (See table 4 in appendix). The titles of the 408 papers that this search returned were screened for matching the criteria (see Figure 1). This initial screening reduced the database to 215 titles that were considered a match or still in need of a closer look. These 215 papers were divided between all authors of this paper, who each reviewed between 10-62 papers. We excluded non-empirical literature which mostly described visions, strategies, guidelines, and theoretical potentials which have not yet been implemented. After screening the abstract for eligibility on all inclusion criteria, a set of 90 papers were left for thorough review by reading the paper in full (See List 1 in Appendix). Papers marked as include were reviewed using a questionnaire developed by the first author based on the two theoretical frameworks that capture diversity in urban food practice and transformative processes and outcomes. This also included descriptive information and methodological details of the articles (See List 2 in Appendix). Adjustments and clarifications to the questionnaire were made after reviewing the first $10 \%$ of the papers. A further 8 papers were excluded after the coding process as upon detailed inspection they did not report on empirical data and urban food initiatives, leading to a total number of 82 reviewed papers (See List 2 in Appendix). The first author cross-checked the final list of reviewed papers for inconsistencies in using the questionnaire.

\section{Clustering of urban food practices}

Multiple research communities are working on various urban food research foci. Research on urban food governance and planning processes for example, unites diverse actors (MoraguesFaus and Marsden, 2017; Morgan, 2013) and showcases the potential of food policy, participatory processes and integrated plans of urban food networks to facilitate urban sustainability (Hebinck and Page, 2017; Matacena, 2016; Sibbing et al., 2019; Sonnino et al., 2019). Farming practices research within the city investigates the ability of urban farms to provide sustainable alternatives for food production in cities, to green cities and to build resilience (Barthel and Isendahl, 2013; Campbell, 2016; Kulak et al., 2013; Martin et al., 2016). Research also explores the community aspects by trying to understand the motivations of gardeners and potential to strengthen social cohesion (Glover et al., 2005; van Holstein, 2017; 
Veen et al., 2016). Other scholars explore alternative modes of food provisioning that can be organised more locally: here, research aims to understand the relation between consumer and producer (Chiffoleau et al., 2016; Dubois, 2019), and the potential that short food supply chains can bring towards sustainability (Berti and Mulligan, 2016; Renting et al., 2003). Somewhat on the fringes of this field is research that explores the educational properties of alternative urban food practices (Cairns, 2017; Hake, 2017), and urban food practices support for both dietary (Ashe and Sonnino, 2012) and mental health (Pedersen et al., 2016). There is also research focussing on social justice in the urban food domain, ranging from exploring urban food assistance (Kneafsey et al., 2017), to (re)claiming space for minorities, and challenging racial and economic inequities (Certomà and Tornaghi, 2015; Loh and Agyeman, 2019; Purcell and Tyman, 2014; Sbicca and Myers, 2017; Wekerle and Classens, 2015). We use these broad categories of research foci (Table 2) as a basis to cluster the urban food practices we found from the literature.

Table 2. Clustering of urban food practices

\begin{tabular}{|c|c|c|}
\hline Urban Food Initiatives & Main research focus & Sources \\
\hline $\begin{array}{l}\text { 1. Food networks and } \\
\text { policy }\end{array}$ & $\begin{array}{l}\text { Potential for food system change; assessing } \\
\text { existing integrated food policies and } \\
\text { strategies; exploring inclusiveness and } \\
\text { participation }\end{array}$ & $\begin{array}{l}\text { Moragues-Faus and Morgan } \\
\text { 2015; Matacena 2016; Hebinck } \\
\text { and Page 2017; Sonnino et al. } \\
2019\end{array}$ \\
\hline $\begin{array}{l}\text { 2. (Peri-)Urban } \\
\text { agriculture }\end{array}$ & $\begin{array}{l}\text { Production of sustainable food in urban } \\
\text { environment; increasing resilience; increasing } \\
\text { number of green urban areas }\end{array}$ & $\begin{array}{l}\text { Kulak et al. 2013; Barthel and } \\
\text { Isendahl 2013; Martin et al. 2016; } \\
\text { Campbell 2016; }\end{array}$ \\
\hline 3. Community gardens & $\begin{array}{l}\text { Contribution to neighbourhood cohesion; } \\
\text { fostering social resilience; allotments as a } \\
\text { source of leisure for urban citizens }\end{array}$ & $\begin{array}{l}\text { Turner et al. 2011; Veen et al. } \\
\text { 2016; Van Holstein 2017; Glover } \\
\text { et al. } 2005\end{array}$ \\
\hline $\begin{array}{l}\text { 4. Short food supply } \\
\text { chains }\end{array}$ & $\begin{array}{l}\text { Developing local, transparent, and equitable } \\
\text { food supply chains; improving proximity } \\
\text { between producer and consumer; improving } \\
\text { rural-urban dynamics }\end{array}$ & $\begin{array}{l}\text { Renting et al. 2003; Chiffoleau et } \\
\text { al. 2016; Berti and Mulligan 2016; } \\
\text { Dubois } 2019\end{array}$ \\
\hline $\begin{array}{l}\text { 5. Care and educational } \\
\text { food initiatives }\end{array}$ & $\begin{array}{l}\text { Fostering food awareness; improving dietary } \\
\text { health; using green space to improve mental } \\
\text { health }\end{array}$ & $\begin{array}{l}\text { Ashe and Sonnino 2012; Pedersen } \\
\text { et al. 2016; Hake 2017; Cairns } \\
2017\end{array}$ \\
\hline $\begin{array}{l}\text { 6. Food justice } \\
\text { organisations }\end{array}$ & $\begin{array}{l}\text { Providing food assistance; (re)claiming space } \\
\text { for minorities; providing space as commons; } \\
\text { challenging racial and economic inequities }\end{array}$ & $\begin{array}{l}\text { Purcell and Tyman 2014; Wekerle } \\
\text { and Classens 2015; Certomà and } \\
\text { Tornaghi 2015; Sbicca and Myers } \\
\text { 2017; Kneafsey et al. 2017; Loh } \\
\text { and Agyeman } 2019\end{array}$ \\
\hline
\end{tabular}

\section{RESULTS}

\section{A descriptive analysis of the literature reviewed}

Figure 2 shows the distribution of the reviewed articles and the urban food practices they reported on over time. Two thirds of the initiatives can be classified as (peri-)urban agriculture (30\%), community gardens $(24 \%)$, or food policy initiatives $(21 \%)$, with the remaining one third shared between food justice organisations (11\%), short food chain initiatives (7\%), and care and educational initiatives (6\%). These studies came from Europe and North America $(67 \%)$, Africa (14\%) and the rest of the continents account for the remaining 19\%. Over $72 \%$ of the studies are performed at the city and city regional spatial scales, with the remaining $28 \%$ spread across neighbourhood, peri-urban, community gardens and other scales (e.g. rooftops). 

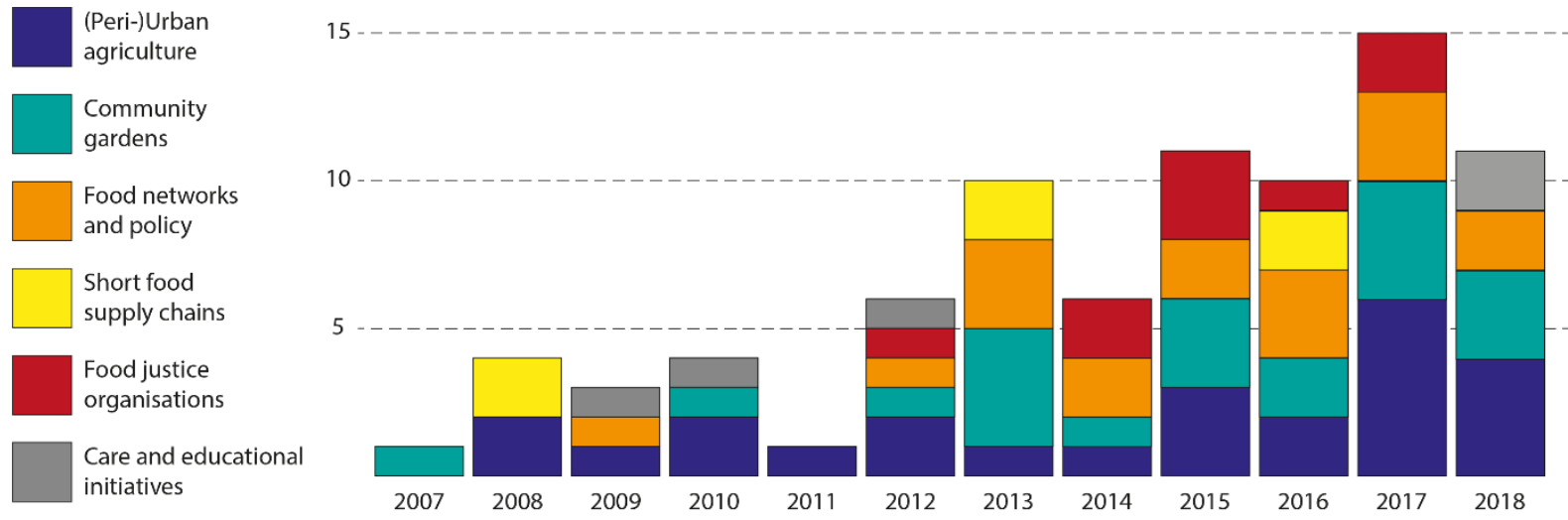

Figure 2. Urban food practice clusters

Most of the papers used qualitative methods (66\%), with the rest using mixed methods (29\%) and quantitative methods (5\%). Papers also spread across several disciplines including social sciences $(30 \%)$, urban studies (16\%), political and interdisciplinary (15\%), environmental studies (12\%), and the remaining $11 \%$ shared by development studies, health studies and economic studies. These studies also used a variety of methods, reflecting this diversity of disciplines (see Figure 3). An extended descriptive analysis is included in Appendix 4.

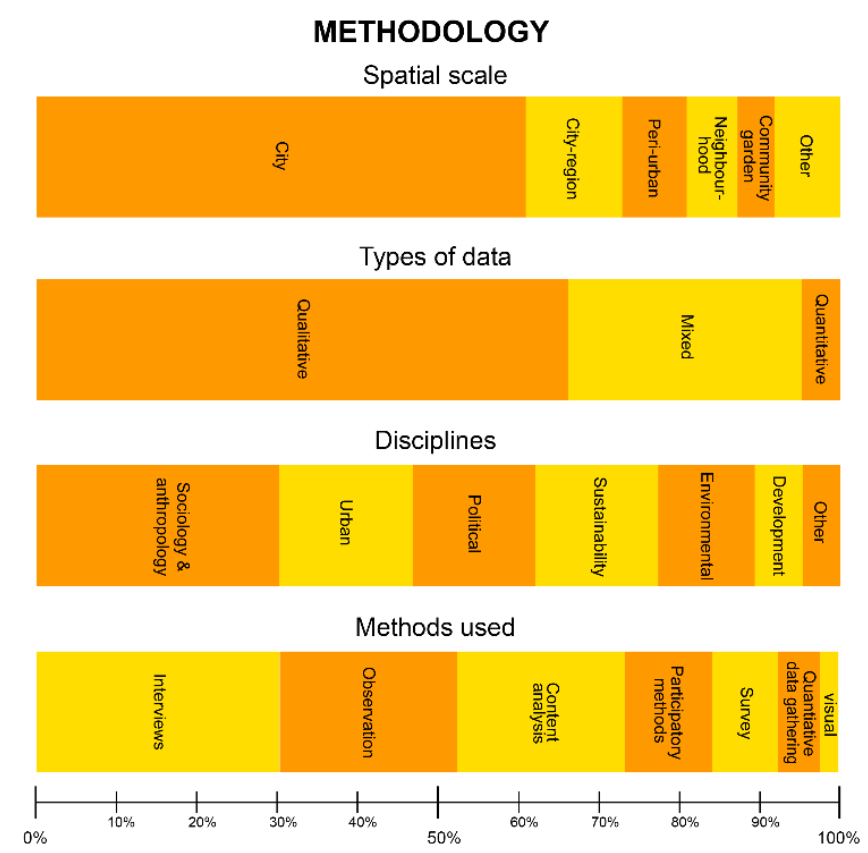

Figure 3. Overview of spatial extent, data, methods and disciplines in the reviewed urban-food literature

A wide variety of a including civil society actors (20\%), public actors (17\%), residents and citizens (16\%), producers (12\%), among others (such as elderly and the poor) were represented, attesting to the grassroots nature of most of these initiatives (see Table 5 appendix for descriptions of actor categories).

\section{Signalling transformative change in urban food practices}

We demonstrate that urban food has potential to support transformative change in various ways (table 3); across all reviewed literature, our signposts for transformation (processes \& 
outcomes) are represented, showing merit to the promise of urban food. However, some are better represented than others.

The most represented transformative processes are the use of participatory approaches (32 papers, numbers henceforth represent the number of papers) and the creation of spatial synergies (26). This shows that urban food practices use some of urban food's key characteristics, such as the ability of food to connect to diverse domains with the aim to create synergies, and as well as its ability to connect to a broad range of actors. Second, the most represented outcomes are the increased (re-)connection to nature (29) and increased ecological resilience (23), showing the potential of urban food to contribute to environmental awareness and sustainable practices. Also well represented is increased self-sufficiency (28), indicating that urban food can provide place-based solutions to increase access to food, and connected flows of resources (20), which can support making urban systems more circular. These processes and outcomes can be considered some of the main contributions of urban food practices.

Table 3. Urban food practices and their reported signposts for transformative change

\begin{tabular}{|c|c|c|c|c|c|c|c|}
\hline Transformative processes & 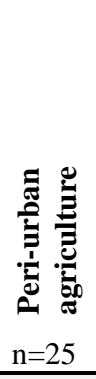 & 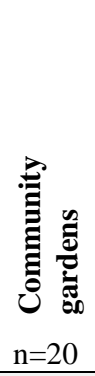 & 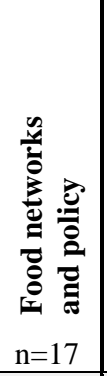 & 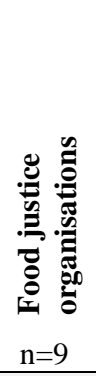 & 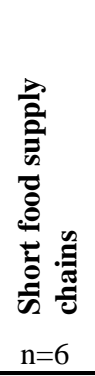 & 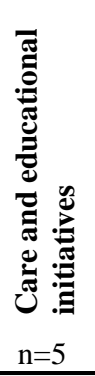 & $\begin{array}{c}\text { స్ } \\
\mathrm{n}=82\end{array}$ \\
\hline Average processes per initiative & $\sim 1,5$ & $\sim 1,2$ & $\sim 2,4$ & $\sim 2,0$ & $\sim 0,8$ & $\sim 2,0$ & - \\
\hline Adoption of a city-region perspective & 6 & 4 & 4 & 3 & 1 & 1 & 19 \\
\hline Creation of spatial synergies & 10 & 1 & 10 & 4 & & 1 & 26 \\
\hline Influencing of consumer decisions & 1 & & 4 & 2 & & 3 & 10 \\
\hline Mobilisation of key actors & 1 & & 2 & & 1 & & 5 \\
\hline Reclaiming or recreating urban space & 4 & 7 & & 1 & 1 & & 13 \\
\hline Strategic planning for the future & 3 & 5 & 4 & 2 & & 1 & 15 \\
\hline Taking an integrated approach & 4 & 2 & 8 & 2 & & 1 & 17 \\
\hline Using participatory approaches & 9 & 4 & 9 & 5 & 2 & 3 & 32 \\
\hline
\end{tabular}

Transformative outcomes

\begin{tabular}{l|c|c|c|c|c|c|c}
\multicolumn{1}{c}{ Average outcomes per initiative } & $\sim 2,8$ & $\sim 2,0$ & $\sim 1,9$ & 1,7 & $\sim 1,8$ & $\sim 2,4$ & - \\
\hline Changed diets & 1 & 2 & 3 & 1 & & 2 & $\mathbf{9}$ \\
\hline Connected flows of resources & 9 & 4 & 4 & 1 & 1 & 1 & $\mathbf{2 0}$ \\
\hline Enhanced transparency & 2 & & 2 & 1 & 2 & & $\mathbf{7}$ \\
\hline Established food governance arrangements & 4 & 5 & 8 & 1 & & & $\mathbf{1 8}$ \\
\hline Greened urban spaces & 2 & 3 & & & & & $\mathbf{5}$ \\
\hline Improved food quality & 4 & & 2 & & 1 & 2 & $\mathbf{9}$ \\
\hline Increased (re-)connection to nature & 12 & 7 & 3 & 3 & 1 & 3 & $\mathbf{2 9}$ \\
\hline Increased ecological resilience & 12 & 3 & 2 & 3 & 2 & 1 & $\mathbf{2 3}$ \\
\hline Increased economic opportunities & 4 & 3 & 1 & & 2 & & $\mathbf{1 0}$ \\
\hline Increased equity in the food chain & 7 & 6 & 3 & 1 & 1 & 1 & $\mathbf{1 9}$ \\
\hline Increased self-sufficiency & 11 & 6 & 5 & 4 & 1 & 1 & $\mathbf{2 8}$ \\
\hline Increased social resilience & 2 & 1 & & & & 1 & $\mathbf{4}$
\end{tabular}

Best reported signposts (20+) are marked in green, averagely represented (10-19) in yellow, and least represented signposts (1-9) in red. Higher (7+) processes and outcomes are represented by light green, medium (3-6) by light yellow, and low (1-2) by light red. 
Several of the signposts such as adoption of a city-region perspective (19) and taking an integrated approach (17) are averagely represented across the research. These two processes indicate the potential to tap into urban-rural dynamics and to contextualise urban food into a wider system which considers various policy objectives. Some processes such as strategic planning for the future (15) show the anticipatory potential to design forward looking interventions. Urban food practices which aim at reclaiming or recreating urban space (13), demonstrate the potential of urban food to facilitate participation in public space for urban dwellers; and those aiming to influence consumer decisions (10) and raise awareness for sustainability can potentially mobilise people to take agency. Practices aiming to increase equity in the food chain (19), highlight urban food as a vehicle to contribute to building justice. Urban food practices that contribute to establishing food governance arrangements (18) are able to provide integrated strategies to address sustainability. Lastly, research also reports on urban food resulting in increased economic opportunities (10) for local food system actors. These processes and outcomes were represented moderately across all reviewed literature, which indicates that while there is potential for urban food to contribute to these, they require more specific attention.

Mobilisation of key actors (5), increased social resilience (4), greened urban spaces (5), enhanced transparency (7), changed diets (9) and improved food quality (9) are featured the least. A possible reason for key actor mobilisation lacking in the literature is because that literature is mostly focused on large, industrial actors that are conceptualised as 'keystone actors' (Folke et al., 2019; Österblom et al., 2015); while the actors in these urban food practices are often operating at a small-scale, and place-based. Similar can be said about the enhanced transparency, which is often considered a crucial point for change for larger actors, such as the food industry, wholesalers, or retailers (Gordon et al., 2017). Interestingly, outcomes that often come to mind when thinking of urban food, such as increased social resilience, greened urban spaces, changed diets and improved food quality are reported on the least in the reviewed papers. A possible reason being that the effects of urban food on these outcomes require a longer-term assessment or that the effects just were not significant. Our findings suggest that there is little potential for urban food to affect change in these topics.

\section{Urban food practice clusters}

We synthesized 6 categories of urban food practices based on the main research focus (see table 2). These include (1) Food networks and policy, (2) (Peri-) Urban agriculture, (3) Short food supply chains, (4) Community (and allotment) gardens, (5) Care and educational food initiatives, and (6) Food justice organisations (Figure 2 and Table 3). Below we show how these individual clusters signal transformative potential.

Each cluster, except those aiming to shorten food supply chains, use between one and two transformative processes (Table 3). Participatory approaches and adopting a city-region perspective were used across all initiative types (Table 3). Considering the wide-ranging number of actors involved, it is no surprise that participatory approaches are used widely. Mobilisation of actors is the least used approach, which may suggest that these initiatives are at a peer to peer level. The peri-urban initiatives appear to employ all 8 transformative processes. However, this is in part due to the higher number of papers reviewed: they employ a similar number of processes and achieve a similar number of outcomes on average as the other initiative types.

All types of initiatives were reported to achieve more than one and up to three potentially transformative outcomes. All types contribute to connecting flows of food-related resources to 
enhance circularity, to connecting people to nature by highlighting amongst others the origin of food, to increasing ecological resilience through more sustainable food production and processing methods, to increasing equity in the food chain by focussing on fair food prices and to increasing regional food self-sufficiency. Interestingly, only a limited number of initiatives are found to contribute to social resilience and greening the urban environment.

\section{Towards a future research agenda}

Since Pothukuchi and Kaufman's seminal paper in 1999, there has been an increase in the recognition of urban food as a site for transformation. The paper sparked diverse research communities to explore emerging urban food phenomena related to their fields, but also led to a proliferation of research departing from diverse viewpoints. We reviewed the fragmented literature on urban food practices, in order to identify signposts for transformative change. We show that there is merit to the promise of urban food to contribute towards transformative change. Our review therefore underscores the value of urban food as a nexus for change. To help harness the transformative potential of urban food, we present three priorities for future research and policy.

First, our work points to the potential of a patchwork of transformative initiatives as a driver for broad, multidimensional change. Our analysis shows that different types of urban food practices (UFP) contribute to one or more transformative processes and outcomes and can therefore support transformations towards more sustainable food systems. Reflecting on diverse theories of change, we argue that several lines of exploration are needed to uncover the dynamics of change through which UFPs impact food systems.

Change is inherently a multi-scalar process (Geels, 2011), suggesting that when processes of change are set in motion by UFPs they might connect to and influence different scales (Dubois, 2019; Loorbach et al., 2020). To better understand the scale character of system interactions, further interrogation of the mechanisms through which UFPs impact broader food system transformations is needed. Our analysis provides insights into the heterogeneous nature of UFPs and shows that their transformative processes and outcomes overlap (table 3). The resilience-based understanding of diversity (Hodbod and Eakin, 2015), suggests that this heterogeneity, overlap and redundancy is a potential strength, as it increases the resilience of urban systems. The diversity of UFPs is thus necessary for reducing dependency on a single initiative to bring change and instead creates a patchwork of transformative initiatives (Biggs et al., 2015). To uncover the role of UFIs in increasing resilience, research unpacking the possibilities for synergies and collaboration between UFIs is needed, as well as research on their ability to withstand shocks and radical processes of change. An on-going example at the time of writing is the COVID-19 pandemic, which has likely limited many urban food initiatives while opening opportunities for others. Such lines of research also connect to the notion that 'small wins' can add up to large-scale and radical change and support the examination of the role of a coalition of diverse UFPs in adding up to food system transformation (Patterson et al., 2017; Termeer and Dewulf, 2019; Wolfram et al., 2019a). Lastly, we argue that more forward-looking and longitudinal research engagements are needed to capture the impact of UFPs on (urban) food system change - as time is an inherent component of processes of change (Hebinck et al., 2018). This will help reveal the directionality of change towards sustainability and clarify who are potential winners and losers of change processes (Kugelberg et al., 2021; Pel et al., 2020). The framework presented in this paper (Table 3) can serve as a foundation to reflect on transformation pathways that feature UFPs as a patchwork, as well as explore their barriers to scaling their practices, what trade-offs they might lead to, or through what mechanisms they interact with incumbent actors. 
Secondly, the different clusters of UFPs and the signposts for transformative change can provide insights to policymakers and planners. For example, on ways to address specific placebased challenges in cities through urban food and how they can better support existing UFPs. Research to interrogate the interactions between, and alignment of, more formal processes of urban food governance and UFPs is needed. Moreover, to strengthen a science-policy connection and support experimentation with diverse configurations of UFPs, we argue for reflexive monitoring, which is crucial for the development of evidence-based ways to justify spending resources on UFIs (Wolfram et al., 2019a). Additionally, this can contribute to providing a more concrete understanding of processes of transformation and therewith help overcome the notion's fuzziness and prevent (ab)use of the term as a metaphor for sustainability (Feola, 2015).

Finally, we identified disciplinary, methodological, and contextual differences between studies of urban food (Figure 3). Despite this fragmentation of research foci, research on diverse practices can be complementary. We contend that integration of and cross pollination of disciplines is crucial for a more comprehensive outlook on the role of UFPs. Exploring ways to integrate disparate areas without stifling research diversity will be crucial. For example, this should include newer types of urban food practices such 'gastronomy innovators' (HigginsDesbiolles et al., 2014; Moskwa et al., 2015; Pereira et al., 2019a) and 'urban food entrepreneurs' (Larsson, 2012; Larsson et al., 2016) which are not captured in our review. Similarly, for those included by fewer papers (e.g. care and educational initiatives) can be explored further. Our review also reveals unequal geography of the research exploring urban food system transformations, with the majority of papers in North American and Western Europe (See Map 1 in the appendix). This imbalance in knowledge production has previously been highlighted specifically for food scholarship (Jehlička et al., 2020), but also more generally for sustainability research (Cornell et al., 2013; Nagendra et al., 2018; Pereira et al., $2019 \mathrm{~b}$ ). As a result, this research is incapable of capturing the distinctly different contexts of urban food practices worldwide and appropriately addressing the different sustainability challenges that are present in diverse contexts. Broader geographical examination of urban food systems and the UFIs that emerge within these systems is essential to utilise the urban food's potential on a global scale (Dolley et al., 2020; Ilieva, 2017).

\section{Conclusion}

The potential change that urban food can induce is increasingly recognised. Through literature analysis of empirical research on urban food practices (UFPs) and their role in furthering sustainable change, we have shown that there are diverse types of UFPs that differently contribute to transformative change. Our framing of this potential using signposts overcomes the temporal challenges that are inherent to evaluating transformative change.

However, to harness this transformative potential for actionable purposes, the nascent field of urban food research requires integration of disciplines and methods and more attention to geographical relevance. Further, a deeper examination of the nature of the transformative potential and reflexive monitoring of the capacities of UFPs are needed. We consider this a step towards providing urban food governance actors with the tools to shape more sustainable urban food systems. More broadly, our signposting framework offers the language to speak about transformation without having to define how realised transformation looks like.

\section{References}

Ashe, L.M., Sonnino, R., 2012. At the crossroads: new paradigms of food security, public health nutrition and school food. Public Health Nutr. 16, 1-8. https://doi.org/10.1017/S1368980012004326

Barthel, S., Isendahl, C., 2013. Urban gardens, Agriculture, And water management: Sources of resilience for long-term food 
security in cities. Ecol. Econ. 86, 224-234. https://doi.org/10.1016/j.ecolecon.2012.06.018

Bennett, E.M., Solan, M., Biggs, R., McPhearson, T., Norström, A. V., Olsson, P., Pereira, L., Peterson, G.D., RaudseppHearne, C., Biermann, F., Carpenter, S.R., Ellis, E.C., Hichert, T., Galaz, V., Lahsen, M., Milkoreit, M., Martin López, B., Nicholas, K.A., Preiser, R., Vince, G., Vervoort, J.M., Xu, J., 2016. Bright spots: seeds of a good Anthropocene. Front. Ecol. Environ. 14, 441-448. https://doi.org/10.1002/fee.1309

Berti, G., Mulligan, C., 2016. Competitiveness of small farms and innovative food supply chains: The role of food hubs in creating sustainable regional and local food systems. Sustain. (United States) 8. https://doi.org/10.3390/su8070616

Biermann, F., Abbott, K., Andresen, S., Bäckstrand, K., Bernstein, S., Betsill, M.M., Bulkeley, H., Cashore, B., Clapp, J., Folke, C., Gupta, A., Gupta, J., Haas, P.M., Jordan, A., Kanie, N., Kluvánková-Oravská, T., Lebel, L., Liverman, D., Meadowcroft, J., Mitchell, R.B., Newell, P., Oberthür, S., Olsson, L., Pattberg, P., Sánchez-Rodríguez, R., Schroeder, H., Underdal, A., Vieira, S.C., Vogel, C., Young, O.R., Brock, A., Zondervan, R., 2012. Transforming governance and institutions for global sustainability: Key insights from the Earth System Governance Project. Curr. Opin. Environ. Sustain. 4, 51-60. https://doi.org/10.1016/j.cosust.2012.01.014

Biggs, R., Schlüter, M., Schoon, M.L., 2015. Principles for building resilience: Sustaining ecosystem services in socialecological systems. Cambridge University Press. https://doi.org/doi.org/10.1017/CBO9781316014240

Blythe, J., Silver, J., Evans, L., Armitage, D., Bennett, N.J., Moore, M.-L., Morrison, T.H., Brown, K., 2018. The Dark Side of Transformation: Latent Risks in Contemporary Sustainability Discourse. Antipode 0, 1-18. https://doi.org/10.1111/anti.12405

Cairns, K., 2017. Children's Geographies Connecting to food: cultivating children in the school garden 3285 . https://doi.org/10.1080/14733285.2016.1221058

Campbell, L.K., 2016. Getting farming on the agenda: Planning, policymaking, and governance practices of urban agriculture in New York City. Urban For. Urban Green. 19, 295-305. https://doi.org/10.1016/j.ufug.2016.03.011

Caron, P., Ferrero y de Loma-Osorio, G., Nabarro, D., Hainzelin, E., Guillou, M., Andersen, I., Arnold, T., Astralaga, M., Beukeboom, M., Bickersteth, S., Bwalya, M., Caballero, P., Campbell, B.M., Divine, N., Fan, S., Frick, M., Friis, A., Gallagher, M., Halkin, J.P., Hanson, C., Lasbennes, F., Ribera, T., Rockstrom, J., Schuepbach, M., Steer, A., Tutwiler, A., Verburg, G., 2018. Food systems for sustainable development: proposals for a profound four-part transformation. Agron. Sustain. Dev. 38. https://doi.org/10.1007/s13593-018-0519-1

Certomà, C., Tornaghi, C., 2015. Political gardening. Transforming cities and political agency. Local Environ. 20, $1123-1131$. https://doi.org/10.1080/13549839.2015.1053724

Chapin, F.S., Pickett, S.T.A., Power, M.E., Jackson, R.B., Carter, D.M., Duke, C., 2011. Earth stewardship: A strategy for social-ecological transformation to reverse planetary degradation. J. Environ. Stud. Sci. 1, 44-53. https://doi.org/10.1007/s13412-011-0010-7

Chiffoleau, Y., Sarah, M.-A.M.-A., Arielle, C., 2016. From short food supply chains to sustainable agriculture in urban food systems: Food democracy as a vector of transition. Agriculture 6, 57. https://doi.org/10.3390/agriculture6040057

Cornell, S., Berkhout, F., Tuinstra, W., Tàbara, J.D., Jäger, J., Chabay, I., de Wit, B., Langlais, R., Mills, D., Moll, P., Otto, I.M., Petersen, A., Pohl, C., van Kerkhoff, L., 2013. Opening up knowledge systems for better responses to global environmental change. Environ. Sci. Policy 28, 60-70. https://doi.org/10.1016/j.envsci.2012.11.008

David Tàbara, J., Frantzeskaki, N., Hölscher, K., Pedde, S., Kok, K., Lamperti, F., Christensen, J.H., Jäger, J., Berry, P., 2018. Positive tipping points in a rapidly warming world. Curr. Opin. Environ. Sustain. 31, 120-129. https://doi.org/10.1016/j.cosust.2018.01.012

Dolley, J., Marshall, F., Butcher, B., Reffin, J., Alexander, J., Baris, R., 2020. Analysing trade - offs and synergies between SDGs for urban development, food security and poverty alleviation in rapidly changing peri - urban areas : a tool to support inclusive urban planning. Sustain. Sci. https://doi.org/10.1007/s11625-020-00802-0

Dubois, A., 2019. Translocal practices and proximities in short quality food chains at the periphery: the case of North Swedish farmers. Agric. Human Values 36, 763-778. https://doi.org/10.1007/s10460-019-09953-y

Elmqvist, T., Andersson, E., Frantzeskaki, N., McPhearson, T., Olsson, P., Gaffney, O., Takeuchi, K., Folke, C., 2019. Sustainability and resilience for transformation in the urban century. Nat. Sustain. 2, $267-273$. https://doi.org/10.1038/s41893-019-0250-1

Feola, G., 2015. Societal transformation in response to global environmental change: A review of emerging concepts. Ambio 44, 376-390. https://doi.org/10.1007/s13280-014-0582-z

Feola, G., Jaworska, S., 2018. One transition, many transitions? A corpus-based study of societal sustainability transition discourses in four civil society's proposals. Sustain. Sci. 1-14. https://doi.org/10.1007/s11625-018-0631-9

Folke, C., Österblom, H., Jouffray, J., Lambin, E.F., Adger, W.N., Scheffer, M., Crona, B.I., Nyström, M., Levin, S.A., Carpenter, S.R., Anderies, J.M., Iii, S.C., Crépin, A., Dauriach, A., Galaz, V., Gordon, L.J., Kautsky, N., Walker, B.H., Watson, J.R., Wilen, J., 2019. Transnational corporations and the challenge of biosphere stewardship. Nat. Ecol. Evol.

Forssell, S., Lankoski, L., 2014. The sustainability promise of alternative food networks: an examination through "alternative" characteristics. Agric. Human Values 63-75. https://doi.org/10.1007/s10460-014-9516-4

Galafassi, D., Daw, T.M., Thyresson, M., Rosendo, S., Chaigneau, T., Bandeira, S., Munyi, L., Gabrielsson, I., Brown, K., 2018. Stories in social-ecological knowledge cocreation. Ecol. Soc. 23. https://doi.org/10.5751/ES-09932-230123

García-sempere, A., Hidalgo, M., Morales, H., Ferguson, B.G., Nazar-beutelspacher, A., Rosset, P., Hidalgo, M., Morales, H., Ferguson, B.G., Ferguson, B.G., 2018. Urban transition toward food sovereignty 7731. https://doi.org/10.1080/14747731.2018.1424285

Geels, F.W., 2011. The multi-level perspective on sustainability transitions: Responses to seven criticisms. Environ. Innov. Soc. transitions 1, 24-40. https://doi.org/10.1016/j.eist.2011.02.002

Gernert, M., El Bilali, H., Strassner, C., 2018. Grassroots Initiatives as Sustainability Transition Pioneers: Implications and Lessons for Urban Food Systems. Urban Sci. 2, 23. https://doi.org/10.3390/urbansci2010023

Glover, T.D., Parry, D.C., Shinew, K.J., 2005. Building relationships, accessing resources: Mobilizing social capital in 
community garden contexts. J. Leis. Res. 37, 450-474. https://doi.org/10.1080/00222216.2005.11950062

Gordon, L.J., Bignet, V., Crona, B., Henriksson, P.J.G., van Holt, T., Jonell, M., Lindahl, T., Troell, M., Barthel, S., Deutsch, L., Folke, C., Haider, J., Rockstroem, J., Queiroz, C., Rockström, J., Queiroz, C., 2017. Rewiring food systems to enhance human health and biosphere stewardship. Environ. Res. Lett. 12.

Hake, B.J., 2017. Gardens as Learning Spaces: Intergenerational Learning in Urban Food Gardens Gardens as Learning Spaces: Intergenerational Learning in. J. Intergener. Relatsh. 15, 26-38. https://doi.org/10.1080/15350770.2017.1260369

Haysom, G., 2015. Food and the City: Urban Scale Food System Governance. Urban Forum 26, $263-281$. https://doi.org/10.1007/s12132-015-9255-7

Hebinck, A., Page, D., 2017. Processes of participation in the development of urban food strategies: A comparative assessment of Exeter and Eindhoven. Sustainability 9, 1-18. https://doi.org/10.3390/su9060931

Hebinck, A., Vervoort, J.M., Hebinck, P., Rutting, L., Galli, F., 2018. Imagining transformative futures : participatory foresight for food systems. Ecol. Soc. 23, 16.

Hebinck, A., Zurek, M., Achterbosch, T., Forkman, B., Kuijsten, A., Kuiper, M., Nørrung, B., van’t Veer, P., Leip, A., 2021. A sustainability compass for policy navigation to sustainable food systems. Glob. Food Sec. 28. https://doi.org/10.31235/osf.io/ab8ts.

Higgins-Desbiolles, F., Moskwa, E., Gifford, S., 2014. The restaurateur as a sustainability pedagogue: the case of Stuart Gifford and Sarah's Sister's Sustainable Café. Ann. Leis. Res. 17, 267-280. https://doi.org/10.1080/11745398.2014.937346

Hodbod, J., Eakin, H., 2015. Adapting a social-ecological resilience framework for food systems. J. Environ. Stud. Sci. 5, 474-484. https://doi.org/10.1007/s13412-015-0280-6

Hölscher, K., Frantzeskaki, N., Loorbach, D., 2019. Steering transformations under climate change: capacities for transformative climate governance and the case of Rotterdam, the Netherlands. Reg. Environ. Chang. 19, 791-805. https://doi.org/10.1007/s10113-018-1329-3

Horst, M., Mcclintock, N., Hoey, L., 2017. The Intersection of Planning, Urban Agriculture, and Food Justice: A Review of the Literature. J. Am. Plan. Assoc. 83, 277-295. https://doi.org/10.1080/01944363.2017.1322914

Ilieva, R.T., 2017. Urban food systems strategies: A promising tool for implementing the SDGs in practice. Sustain. 9. https://doi.org/10.3390/su9101707

IPES Food, 2017. What Makes Urban Food Policy Happen? Insights from five case studies.

IPES Food, 2015. The New Science of Sustainable Food Systems: Overcoming Barriers to Food Systems Reform.

Jarosz, L., 2008. The city in the country: Growing alternative food networks in Metropolitan areas. J. Rural Stud. 24, 231244. https://doi.org/10.1016/j.jrurstud.2007.10.002

Jehlička, P., Grīviņš, M., Visser, O., Balázs, B., 2020. Thinking food like an East European: A critical reflection on the framing of food systems. J. Rural Stud. 76, 286-295. https://doi.org/10.1016/j.jrurstud.2020.04.015

Kasper, C., Brandt, J., Lindschulte, K., Giseke, U., 2017. The urban food system approach: thinking in spatialized systems. Agroecol. Sustain. Food Syst. 41, 1009-1025. https://doi.org/10.1080/21683565.2017.1334737

Kneafsey, M., Owen, L., Bos, E., Broughton, K., Lennartsson, M., 2017. Capacity building for food justice in England: the contribution of charity-led community food initiatives. Local Environ. 22, 621-634. https://doi.org/10.1080/13549839.2016.1245717

Kopp, R.E., Shwom, R.L., Wagner, G., Yuan, J., 2016. Tipping elements and climate-economic shocks: Pathways toward integrated assessment. Earth's Futur. 4, 346-372. https://doi.org/10.1002/2016EF000362

Kugelberg, S., Bartolini, F., Kanter, D.R., Milford, A.B., Pira, K., Sanz-Cobena, A., Leip, A., 2021. Implications of a food system approach for policy agenda-setting design. Glob. Food Sec. 28. https://doi.org/10.1016/j.gfs.2020.100451

Kulak, M., Graves, A., Chatterton, J., 2013. Reducing greenhouse gas emissions with urban agriculture: A Life Cycle Assessment perspective. Landsc. Urban Plan. 111, 68-78. https://doi.org/10.1016/j.landurbplan.2012.11.007

Lam, D.P.M., Martín-López, B., Wiek, A., Bennett, E.M., Frantzeskaki, N., Horcea-Milcu, A.I., Lang, D.J., 2020. Scaling the impact of sustainability initiatives: a typology of amplification processes. Urban Transform. 2. https://doi.org/10.1186/s42854-020-00007-9

Larsson, M., 2012. Environmental Entrepreneurship in Organic Agriculture in Järna, Sweden. J. Sustain. Agric. 36, $153-179$. https://doi.org/10.1080/10440046.2011.620225

Larsson, M., Milestad, R., Hahn, T., von Oelreich, J., 2016. The resilience of a sustainability entrepreneur in the Swedish food system. Sustain. 8. https://doi.org/10.3390/su8060550

Leach, M., Rockström, J., Raskin, P., Scoones, I.C., Stirling, A.C.A.C., Smith, A., Thompson, J., Millstone, E., Ely, A., Arond, E., Folke, C., Olsson, P., Rokstrom, J., Raskin, P., Scoones, I.C., Stirling, A.C.A.C., Smith, A., Thompson, J., Millstone, E., Ely, A., Arond, E., Rockström, J., Raskin, P., Scoones, I.C., Stirling, A.C.A.C., Smith, A., Thompson, J., Millstone, E., Ely, A., Arond, E., Folke, C., Olsson, P., 2012. Transforming innovation for sustainability. Ecol. Soc. 17, 11. https://doi.org/org/10.5751/ES-04933-170211

Levkoe, C.Z., 2011. Towards a transformative food politics. Local Environ. 16, $687-705$. https://doi.org/10.1080/13549839.2011.592182

Loh, P., Agyeman, J., 2019. Urban food sharing and the emerging Boston food solidarity economy. Geoforum 99, $213-222$. https://doi.org/10.1016/j.geoforum.2018.08.017

Loorbach, D., Frantzeskaki, N., Avelino, F., 2017. Sustainability Transitions Research: Transforming Science and Practice for Societal Change. Annu. Rev. Environ. Resour. 42, 599-626. https://doi.org/10.1146/annurev-environ-102014-021340

Loorbach, D., Wittmayer, J., Avelino, F., von Wirth, T., Frantzeskaki, N., 2020. Transformative innovation and translocal diffusion. Environ. Innov. Soc. Transitions 1-10. https://doi.org/10.1016/j.eist.2020.01.009

Marsden, T., 2013. Sustainable place-making for sustainability science: The contested case of agri-food and urban-rural relations. Sustain. Sci. 8, 213-226. https://doi.org/10.1007/s11625-012-0186-0 
Martin, G., Clift, R., Christie, I., 2016. Urban cultivation and its contributions to sustainability: Nibbles of food but oodles of social capital. Sustain. 8. https://doi.org/10.3390/su8050409

Matacena, R., 2016. Linking alternative food networks and urban food policy: a step forward in the transition towards a sustainable and equitable food system? Int. Rev. Soc. Res. 6, 49-58. https://doi.org/10.1515/irsr-2016-0007

McCormick, K., Anderberg, S., Coenen, L., Neij, L., 2013. Advancing sustainable urban transformation. J. Clean. Prod. 50, 1-11. https://doi.org/10.1016/j.jclepro.2013.01.003

Moore, M.L., Tjornbo, O., Enfors, E., Knapp, C., Hodbod, J., Baggio, J.A., Norström, A., Olsson, P., Biggs, D., 2014. Studying the complexity of change: Toward an analytical framework for understanding deliberate social-ecological transformations. Ecol. Soc. 19. https://doi.org/10.5751/ES-06966-190454

Moragues-Faus, A.M., Carroll, B., 2018. Reshaping urban political ecologies: an analysis of policy trajectories to deliver food security. Food Secur. https://doi.org/10.1007/s12571-018-0855-7

Moragues-Faus, A.M., Marsden, T., 2017. The political ecology of food: Carving 'spaces of possibility' in a new research agenda. J. Rural Stud. 55, 275-288. https://doi.org/10.1016/j.jrurstud.2017.08.016

Moragues-Faus, A.M., Morgan, K., 2015. Reframing the foodscape: the emergent world of urban food policy. Environ. Plan. A 47, 1558-1573. https://doi.org/10.1177/0308518X15595754

Morgan, K., 2013. The Rise of Urban Food Planning. Int. Plan. Stud. 18, 1-4. https://doi.org/10.1080/13563475.2012.752189

Moskwa, E., Higgins-Desbiolles, F., Gifford, S., 2015. Sustainability through food and conversation: the role of an entrepreneurial restaurateur in fostering engagement with sustainable development issues. J. Sustain. Tour. 23, 126145. https://doi.org/10.1080/09669582.2014.940046

Nagendra, H., Bai, X., Brondizio, E.S., Lwasa, S., 2018. The urban south and the predicament of global sustainability. Nat. Sustain. 1, 341-349. https://doi.org/10.1038/s41893-018-0101-5

O’Brien, K., 2012. Global environmental change II: From adaptation to deliberate transformation. Prog. Hum. Geogr. 36, 667676. https://doi.org/10.1177/0309132511425767

Österblom, H., Jouffray, J.B., Folke, C., Crona, B., Troell, M., Merrie, A., Rockström, J., 2015. Transnational corporations as "keystone actors" in marine ecosystems. PLoS One 10, 1-15. https://doi.org/10.1371/journal.pone.0127533

Patterson, J.J., Schulz, K., Vervoort, J.M., Hel, S. Van Der, Sethi, M., Barau, A., 2017. Exploring the governance and politics of transformations towards sustainability. Environ. Innov. Soc. Transitions 24, 1-16. https://doi.org/https://doi.org/10.1016/j.eist.2016.09.001

Pedersen, I., Patil, G., Berget, B., Ihlebæk, C., Thorsen, M., 2016. Mental health rehabilitation in a care farm context: A descriptive review of Norwegian intervention studies 53, 31-43. https://doi.org/10.3233/WOR-152213

Pel, B., Raven, R., Est, R. Van, 2020. Transitions governance with a sense of direction: synchronization challenges in the case of the dutch 'Driverless Car' transition. Technol. Forecast. Soc. Chang. 160, 120244. https://doi.org/10.1016/j.techfore.2020.120244

Pereira, L., Calderón-Contreras, R., Norström, A. V., Espinosa, D., Willis, J., Guerrero Lara, L., Khan, Z., Rusch, L., Correa Palacios, E., Pérez Amaya, O., 2019a. Chefs as change-makers from the kitchen: indigenous knowledge and traditional food as sustainability innovations. Glob. Sustain. 2. https://doi.org/10.1017/s2059479819000139

Pereira, L., Frantzeskaki, N., Hebinck, A., Charli-joseph, L., Drimie, S., Dyer, M., Eakin, H., Galafassi, D., Karpouzoglou, T., Marshall, F., Moore, L., Olsson, P., Zwanenberg, P. Van, Vervoort, J.M., 2019b. Transformative spaces in the making: key lessons from 9 cases in the Global South. Sustain. Sci. 44. https://doi.org/10.1007/s11625-019-00749-x

Pothukuchi, K., Kaufman, J.L., 1999. Placing the food system on the urban agenda: The role of municipal institutions in food systems planning. Agric. Human Values 16, 213-224. https://doi.org/10.1023/a:1007558805953

Purcell, M., Tyman, S.K., 2014. Cultivating food as a right to the city. Local Environ. Int. J. Justice Sustain. 9839, 1-16. https://doi.org/10.1080/13549839.2014.903236

Renting, H., Marsden, T.K., Banks, J., 2003. Understanding alternative food networks: Exploring the role of short food supply chains in rural development. Environ. Plan. A 35, 393-411.

Rocha, J.C., Peterson, G.D., Biggs, R., 2015. Regime shifts in the anthropocene: Drivers, risks, and resilience. PLoS One 10, 10-12. https://doi.org/10.1371/journal.pone.0134639

Sbicca, J., Myers, J.S., 2017. Food justice racial projects: fighting racial neoliberalism from the Bay to the Big Apple. Environ. Sociol. 3, 30-41. https://doi.org/10.1080/23251042.2016.1227229

Scoones, I., Stirling, A., Abrol, D., Atela, J., Charli-Joseph, L., Eakin, H., Ely, A., Olsson, P., Pereira, L., Priya, R., van Zwanenberg, P., Yang, L., 2020. Transformations to sustainability: combining structural, systemic and enabling approaches. Curr. Opin. Environ. Sustain. 42, 65-75. https://doi.org/10.1016/j.cosust.2019.12.004

Sharpe, B., Hodgson, A., Leicester, G., Lyon, A., Fazey, I., 2016. Three horizons: A pathways practice for transformation. Ecol. Soc. 21. https://doi.org/10.5751/ES-08388-210247

Shove, E., 2010. Beyond the ABC: Climate change policy and theories of social change. Environ. Plan. A 42, $1273-1285$. https://doi.org/10.1068/a42282

Sibbing, L., Candel, J., Termeer, K., 2019. A comparative assessment of local municipal food policy integration in the Netherlands. Int. Plan. Stud. 0, 1-14. https://doi.org/10.1080/13563475.2019.1674642

Sonnino, R., 2009. Feeding the City: Towards a New Research and Planning Agenda. Int. Plan. Stud. 14, 425-435.

Sonnino, R., Tegoni, C.L.S., Cunto, A. De, 2019. The challenge of systemic food change : Insights from cities. Cities 85, 110116. https://doi.org/10.1016/j.cities.2018.08.008

Termeer, C.J.A.M., Dewulf, A., 2019. A small wins framework to overcome the evaluation paradox of governing wicked problems. Policy Soc. 38, 298-314. https://doi.org/10.1080/14494035.2018.1497933

Termeer, C.J.A.M., Metze, T.A.P., 2019. More than peanuts: Transformation towards a circular economy through a smallwins governance framework. J. Clean. Prod. 240, 118272. https://doi.org/10.1016/j.jclepro.2019.118272

Torrens, J., Schot, J., Raven, R., Johnstone, P., 2019. Seedbeds, harbours, and battlegrounds: On the origins of favourable environments for urban experimentation with sustainability. Environ. Innov. Soc. Transitions 31, 211-232. 
https://doi.org/10.1016/j.eist.2018.11.003

van Holstein, E., 2017. Relating to nature, food and community in community gardens. Local Environ. 22, $1159-1173$. https://doi.org/10.1080/13549839.2017.1328673

Veen, E.J., Bock, B.B., Van den Berg, W., Visser, A.J., Wiskerke, J.S.C., 2016. Community gardening and social cohesion: different designs, different motivations. Local Environ. 21, 1271-1287. https://doi.org/10.1080/13549839.2015.1101433

Vieira, L.C., Serrao-Neumann, S., Howes, M., Mackey, B., 2018. Unpacking components of sustainable and resilient urban food systems. J. Clean. Prod. 200, 318-330. https://doi.org/10.1016/j.jclepro.2018.07.283

von Wirth, T., Fuenfschilling, L., Frantzeskaki, N., Coenen, L., 2019. Impacts of urban living labs on sustainability transitions: mechanisms and strategies for systemic change through experimentation. Eur. Plan. Stud. 27, $229-257$. https://doi.org/10.1080/09654313.2018.1504895

Wekerle, G.R., Classens, M., 2015. Food production in the city: (re)negotiating land, food and property. Local Environ. 9839 , 1-19. https://doi.org/10.1080/13549839.2015.1007121

Wiek, A., Ness, B., Schweizer-Ries, P., Brand, F.S., Farioli, F., 2012. From complex systems analysis to transformational change: A comparative appraisal of sustainability science projects. Sustain. Sci. 7, 5-24. https://doi.org/10.1007/s11625-011-0148-y

Wiskerke, J.S.C., Viljoen., A., 2012. Sustainable urban food provisioning: Challenges for scientists, policymakers, planners and designers, in: Viljoen, A., Wiskerke, J.S.C. (Eds.), Sustainable Food Planning: Evolving Theory and Practic. Wageningen Academic-Publishers, Wageningen, pp. 19-35.

Wiskerke, Johannes S.C. C., 2015. Urban food systems, in: de Zeeuw, H., Drechsel, P. (Eds.), Cities and Agriculture: Developing Resilient Urban Food Systems. Routledge, London, pp. 1-25.

Wiskerke, Johannes S.C. C, 2015. Urban food systems, in: de Zeeuw, H., Drechsel, P. (Eds.), Cities and Agriculture: Developing Resilient Urban Food Systems. Routledge, London, pp. 1-25.

Wolfram, M., Borgström, S., Farrelly, M., 2019a. Urban transformative capacity: From concept to practice. Ambio 48, 437448. https://doi.org/10.1007/s13280-019-01169-y

Wolfram, M., van der Heijden, J., Juhola, S., Patterson, J., 2019b. Learning in urban climate governance: concepts, key issues and challenges. J. Environ. Policy Plan. 21, 1-15. https://doi.org/10.1080/1523908X.2018.1558848 


\section{Appendix}

\section{Appendix 1. Glossary}

Urban food practices encompass activities that are directly related to food such as growing, serving, designing policies for and about food, and other activities that take place in urban food systems

Urban food systems are made up of networks of actors that perform food-related activities that result in food-related outcomes in (peri-)urban regions.

Transformation is understood as 'fundamental change' that affects the structures, functioning, and interrelations of a given system.

Sustainability transformations are fundamental systemic changes directed towards sustainability.

Signposts for transformative change are processes and outcomes that point into the direction of desired food system transformation.

Transformative processes are processes that are considered to lead to desired outcomes or build on principles that are considered vital for transformation, as described in the literature.

Transformative outcomes are outcomes that are considered to align with outcomes of desired food system transformation, as described in literature.

\section{Appendix 2.}

Table 4. Database, keywords and search algorithm used in the literature search

\begin{tabular}{ll}
\hline Database & Key words and search algorithm \\
\hline Scopus & TITLE-ABS-KEY ( ( ( ( urban OR city* OR town ) W/1 ( food OR agriculture OR garden* \\
& $\begin{array}{l}\text { OR farm* })) \text { AND ( sustainab* OR resilien* OR transit* OR transform* }) \text { AND ( case OR } \\
\text { project* OR initiative* OR organisation* OR enterprise* })))\end{array}$ \\
\hline
\end{tabular}




\section{Appendix 3.}

Table 5. Food system actors and activities that are considered part of urban food systems

\begin{tabular}{|c|c|}
\hline Food system actors & Description \\
\hline Food producers & Primary production by farmers, fisherfolk etc. \\
\hline Food processing actors & Processing, packaging, and distribution of food \\
\hline Retail actors & Supermarkets, wholesale markets \\
\hline Consumers & Actors who buy food for consumption \\
\hline Residents and citizens & People living within a certain vicinity of a space \\
\hline Vulnerable actors & Target groups of interventions, poor, elderly, migrants, etc. \\
\hline Civil society actors & Social movements, a community, volunteers, NGOs, \\
\hline Private actors & Businesses, restaurants, farm shops, farmers markets \\
\hline Public actors & Decision makers at various levels: national, regional, city \\
\hline Academia and experts & $\begin{array}{l}\text { Actors with high level of knowledge about the functioning of a specific part of the } \\
\text { urban food system, scientists, urban planners. }\end{array}$ \\
\hline Food system activities & Description \\
\hline Social & $\begin{array}{l}\text { The initiative creates or strengthens communities and social ties, and/or supports } \\
\text { communication and cohesion }\end{array}$ \\
\hline Economic & $\begin{array}{l}\text { The initiative creates jobs, supports local economic activity and/or promotes a } \\
\text { viable business model }\end{array}$ \\
\hline Environmental & $\begin{array}{l}\text { The initiative is sustainable or beneficial to the environment in terms of nature, } \\
\text { waste, energy, soil, water, and air }\end{array}$ \\
\hline Education & $\begin{array}{l}\text { The initiative teaches food skills and promotes awareness about food, health, and } \\
\text { the environment }\end{array}$ \\
\hline Health & $\begin{array}{l}\text { The initiative provides affordable, nutritious, fresh, and/or healthy food, and/or } \\
\text { supports a positive public health agenda }\end{array}$ \\
\hline Governance & $\begin{array}{l}\text { The initiative contributes to policy making and/or governing of institutions or } \\
\text { important functions of the food system }\end{array}$ \\
\hline Liveability & $\begin{array}{l}\text { The initiative creates interactive spaces, helps to reduce anti-social behaviour, } \\
\text { and/or provides urban amenities from cultural events and cafés to attractive and } \\
\text { edible green space }\end{array}$ \\
\hline Equity & $\begin{array}{l}\text { The initiative contributes to the reduction of poverty by making vulnerable groups } \\
\text { more food self-sufficient }\end{array}$ \\
\hline Infrastructure & $\begin{array}{l}\text { The initiative contributes to the food infrastructure in terms of growing sites, } \\
\text { community platforms, transportation and/or planning }\end{array}$ \\
\hline Social care & The initiative contributes to the care and/or therapy of people \\
\hline
\end{tabular}




\section{Appendix 4. \\ Extended descriptive analysis}

The majority of the studies included in our review come from Europe and North America (67\%), with Africa following at 14\% and the rest of the continents below 10\%. Looking at individual countries (see Figure 4), the top 5 countries were the United States (24 papers, 30\%), the United Kingdom (12 papers, 15\%), both Brazil and Canada (each 6 papers, $7 \%$ ) and both Italy and South Africa (each 5 papers, 6\%). Figure 3 in the manuscript shows the distribution of methodological and food system patterns of research on UFP indicated through the review. Over $72 \%$ of the studies are performed at the city and city regional spatial scales, with the remaining $28 \%$ spread across neighbourhood, peri-urban, community gardens and other scales (e.g. rooftops).

Figure 4. Geographical spread of reviewed urban food research

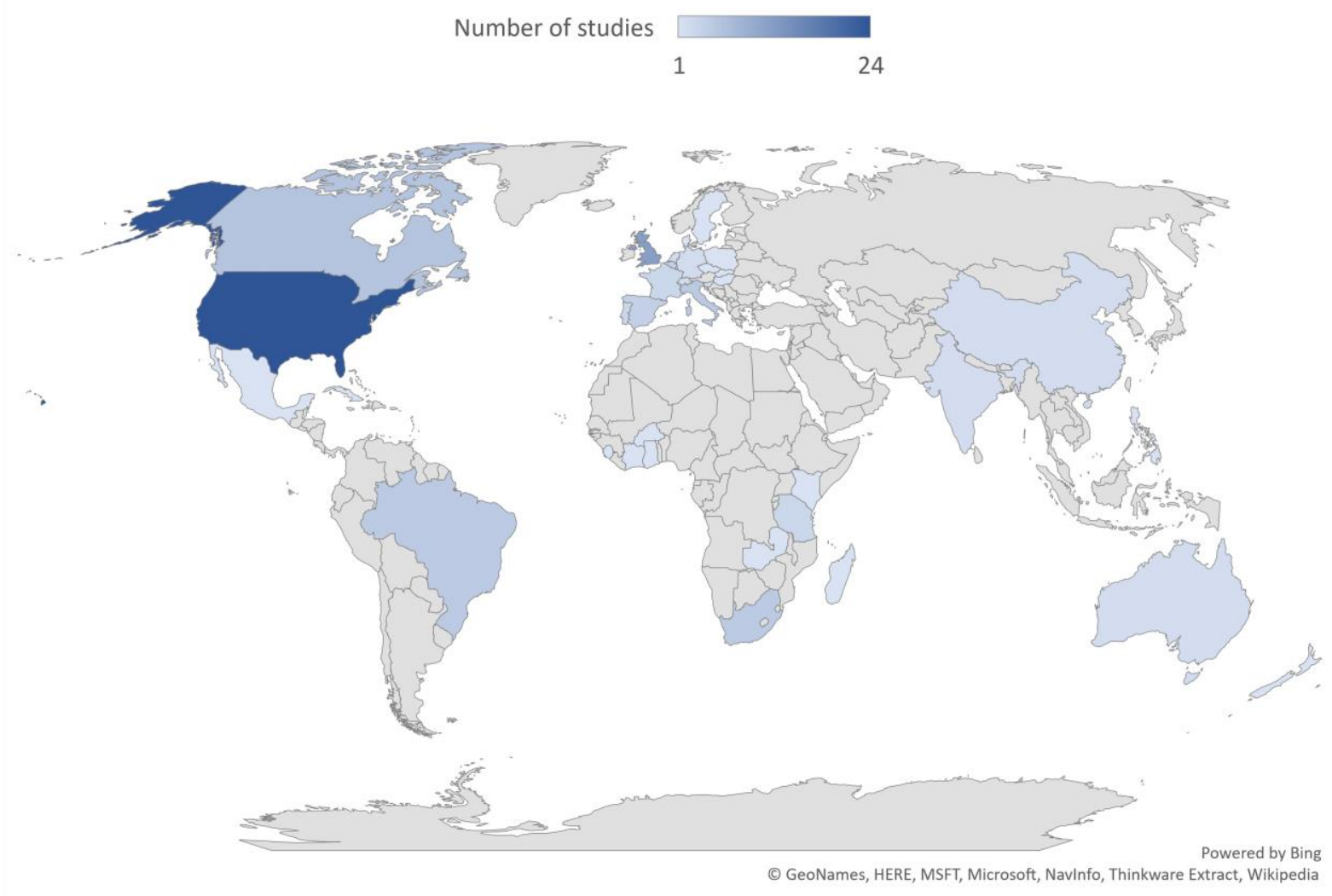

Most of the papers used qualitative methods (66\%), with the rest using mixed methods (29\%) and quantitative methods (5\%). Disciplinary spread in the reviewed papers is high, with $30 \%$ in social sciences research, $16 \%$ in urban studies, $15 \%$ both in political and in interdisciplinary studies, $12 \%$ in environmental studies, and the remaining $11 \%$ shared by development studies, health studies and economic studies. This disciplinary spread is reflected in the specific methods used: $31 \%$ of the studies used interviews, $22 \%$ used observational methods, $21 \%$ used content analysis (ranging from databases to grey literature), $11 \%$ used participatory methods, and the remaining $15 \%$ used surveys, quantitative data gathering or visual documentation.

Two thirds of the initiatives can be classified as (peri-)urban agriculture (30\%), community gardens $(24 \%)$, or food policy initiatives $(21 \%)$, with the remaining one third shared between food justice organisations (11\%), short food chain initiatives $(7 \%)$, and care and educational initiatives (6\%). Figure 2 in the manuscript shows the distribution of the reviewed articles and the UFPs they reported on over time. A wide variety of actors is involved in the urban food 
initiatives researched. Among these are civil society actors (20\%), public actors (17\%), residents and citizens $(16 \%)$ and producers $(12 \%)$, with the rest made up by marginalized actors (such as elderly and the poor) consumers and private actors, as well as academic actors. The type of actors involved attest to the grassroots nature of most of these initiatives.

\section{Actors}

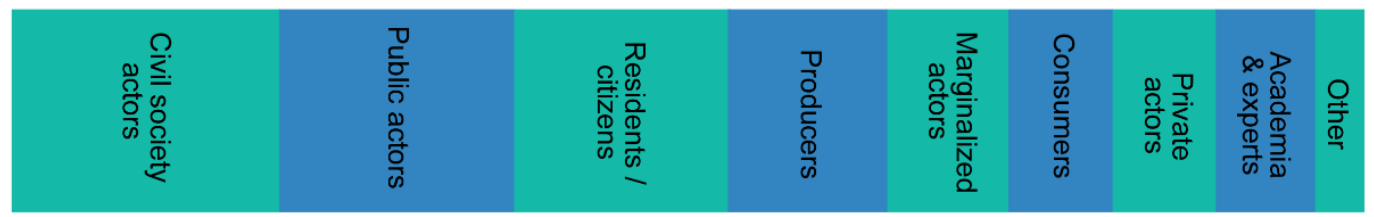

Activities

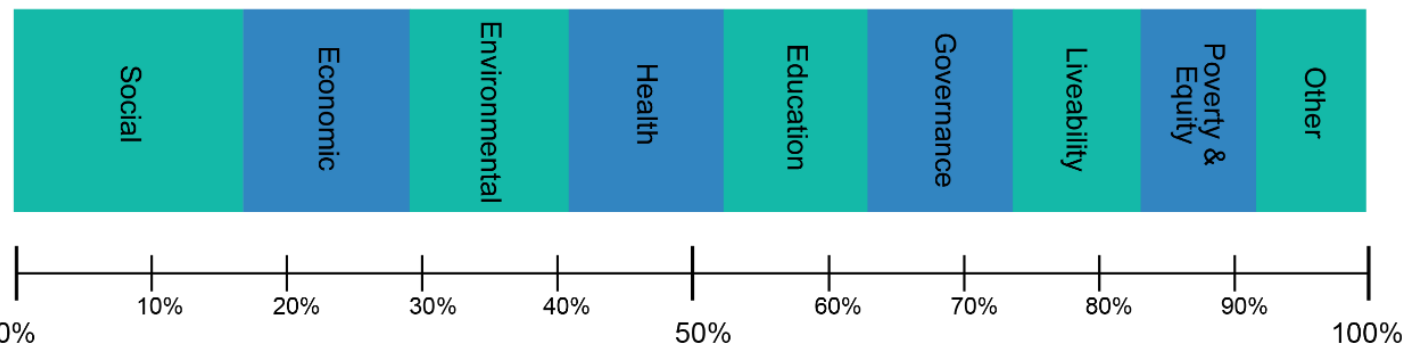

Figure 5. Overview of actors and activities reported in the reviewed literature

Similar to the diversity of actors involved, the activities reflect a variety of objectives: $17 \%$ of the UFPs studied focus on social activities, which involves creating or strengthening communities and social ties. A further $12 \%$ focus on economic activities which create jobs or support local economies and another $12 \%$ on environmental activities to increase ecological sustainability. About $11 \%$ focus on health and on education activities, and $10 \%$ both on governance and on liveability activities, with the remaining activities focused on poverty reduction, increasing equity or infrastructure.

Using this framework, we explored the transformative characteristics of UFP research by unpacking what processes and outcomes are reported on (Table 3 in the manuscript). We found that transformative processes most often used were participatory approaches to engage actors in the process $(25 \%)$, creating spatial synergies (18\%), adopting a city-region perspective $(14 \%)$, using an integrated approach to capture the interconnected nature of food systems $(13 \%)$, strategically planning for the future $(10 \%)$, or aiming to influence actor's decisions (7\%). The remaining processes focus on reclaiming urban spaces and mobilising key actors. In terms of transformative outcomes, UFPs most commonly aim to contribute to increased selfsufficiency (16\%) and reconnect people to food and nature (16\%). They also intend to increase the resilience of production systems (12\%), connect flows and resources (11\%), establish food networks or policy (10\%), and increase equity (10\%), economic opportunities $(6 \%)$, or food quality (5\%). Finally, a smaller number of UFPs focus on the changing of diets towards more sustainable and healthier food (4\%), increasing transparency between producers and consumers $(4 \%)$, increasing social resilience $(4 \%)$, and greening urban spaces $(3 \%)$. This is summarized in Figure 6. 
Transformative processes

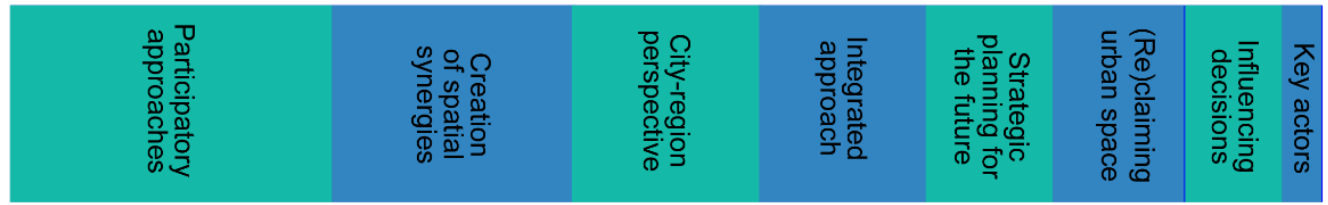

Transformative outcomes
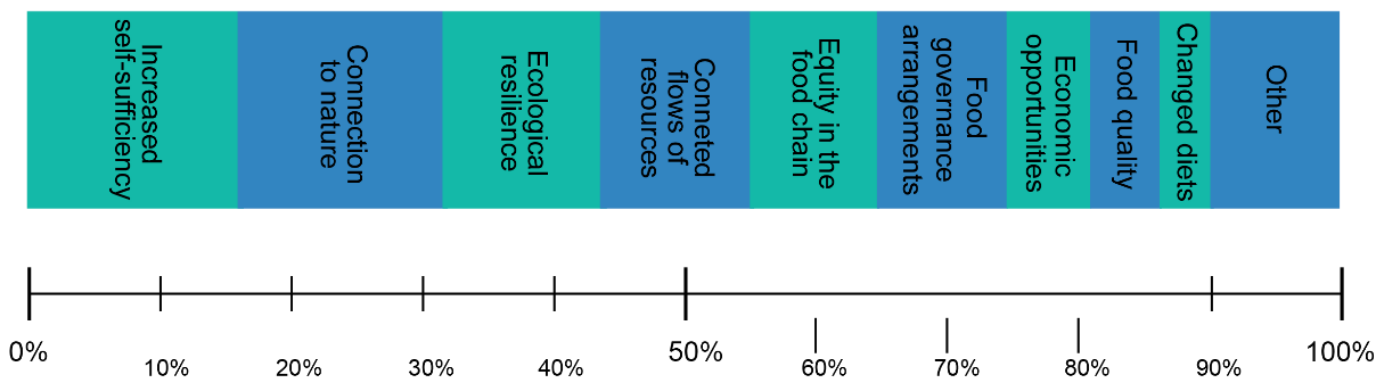

Figure 6. Overview of the transformative processes and outcomes reported in the reviewed literature 


\section{Appendix 5.}

\section{List 1. Papers included in the review}

1. Alkon, A. Paradise or pavement: the social constructions of the environment in two urban farmers' markets and their implications for environmental justice and sustainability. Local Environ. 13, 271-289 (2008).

2. Aubry, C. \& Kebir, L. Shortening food supply chains: A means for maintaining agriculture close to urban areas? The case of the French metropolitan area of Paris. Food Policy 41, 85-93 (2013).

3. Aubry, C. et al. Urban agriculture and land use in cities: An approach with the multi-functionality and sustainability concepts in the case of Antananarivo (Madagascar). Land use policy 29, 429-439 (2012).

4. Babo, A. Sociopolitical crisis and the reconstruction of sustainable periurban agriculture in abidjan, Côte d'Ivoire. Afr. Stud. Rev. 53, 101-120 (2010).

5. Battersby, J. \& Marshak, M. Growing Communities: Integrating the Social and Economic Benefits of Urban Agriculture in Cape Town. Urban Forum 24, 447-461 (2013).

6. Bellwood-Howard, I., Shakya, M., Korbeogo, G. \& Schlesinger, J. The role of backyard farms in two West African urban landscapes. Landscape and Urban Planning (2017). doi:10.1016/j.landurbplan.2017.09.026

7. Bhatt, V., Farah, L. M., Luka, N. \& Wolfe, J. M. Making the Edible Campus: A model for food-secure urban revitalisation. Open House Int. 34, 81-90 (2009).

8. Cabannes, Y. \& Raposo, I. Peri-urban agriculture, social inclusion of migrant population and Right to the City: Practices in Lisbon and London. City 17, 235-250 (2013).

9. Camps-Calvet, M., Langemeyer, J., Calvet-Mir, L., Gómez-Baggethun, E. \& March, H. Sowing resilience and contestation in times of crises: The case of urban gardening movements in Barcelona. Partecip. e Conflitto 8, 417-442 (2015).

10. Cangelosi, E. Reshaping spaces and relations: Urban gardening in a time of crisis. Partecip. e Conflitto 8, 392-416 (2015).

11. Certomà, C. 'a New Season for Planning': Urban Gardening As Informal Planning in Rome. Geogr. Ann. Ser. B Hum. Geogr. 98, 109-126 (2016).

12. Certomà, C. \& Notteboom, B. Informal planning in a transactive governmentality. Re-reading planning practices through Ghent's community gardens. Plan. Theory 16, 51-73 (2017).

13. Chang, M. \& Morel, K. Reconciling economic viability and socio-ecological aspirations in London urban microfarms. Agronomy for Sustainable Development 38, (2018).

14. Chappell, M. J., Moore, J. R. \& Heckelman, A. A. Participation in a city food security program may be linked to higher ant alpha- and beta-diversity: an exploratory case from Belo Horizonte, Brazil. Agroecol. Sustain. Food Syst. 40, 804-829 (2016).

15. Chiffoleau, Y., Sarah, M.-A. M.-A. \& Arielle, C. From short food supply chains to sustainable agriculture in urban food systems: Food democracy as a vector of transition. Agriculture 6, 57 (2016).

16. Cohen, N. \& Reynolds, K. Resource needs for a socially just and sustainable urban agriculture system: Lessons from New York City. Renew. Agric. Food Syst. 30, 103-114 (2015).

17. Cook, J., Oviatt, K., Main, D. S., Kaur, H. \& Brett, J. Re-conceptualizing urban agriculture: an exploration of farming along the banks of the Yamuna River in Delhi, India. Agric. Human Values 32, 265-279 (2015).

18. Davies, A. R. et al. Creative construction: crafting, negotiating and performing urban food sharing landscapes. Area 49, 510-518 (2017).

19. Delgado, C. Mapping urban agriculture in Portugal: Lessons from practice and their relevance for European post-crisis contexts. Morav. Geogr. Reports 25, 139-153 (2017).

20. DeLind, L. B. Where have all the houses (among other things) gone? Some critical reflections on urban agriculture. Renew. Agric. Food Syst. 30, 3-7 (2015).

21. Diekmann, L. O., Gray, L. C. \& Baker, G. A. Drought, water access, and urban agriculture: a case study from Silicon Valley. Local Environment 22, 1394-1410 (2017).

22. Domene, E. \& Saurí, D. Urbanization and class-produced natures: Vegetable gardens in the Barcelona Metropolitan Region. Geoforum 38, 287-298 (2007).

23. Dubbeling, M. et al. Assessing and planning sustainable city region food systems: Insights from two Latin American cities. Sustainability (Switzerland) 9, (2017).

24. Dunlap, R., Harmon, J. \& Kyle, G. Growing in place: the interplay of urban agriculture and place sentiment. Leisure/ Loisir 37, 397-414 (2013).

25. Dutta, D. \& Chandrasekharan, S. Doing to being: farming actions in a community coalesce into proenvironment motivations and values. Environ. Educ. Res. 24, 1192-1210 (2018).

26. Fesenfeld, L. P. Governing urban food systems in the long run: Comparing best practices in sustainable 
food procurement regulations. Gaia $\mathbf{2 5}, 260-270$ (2016).

27. Gasperi, D. et al. Towards regenerated and productive vacant areas through urban horticulture: Lessons from Bologna, Italy. Sustain. 8, (2016).

28. Grard, B. J. P. et al. Rooftop farming on urban waste provides many ecosystem services. Agron. Sustain. Dev. 38, (2018).

29. Halloran, A. \& Magid, J. Planning the unplanned: Incorporating agriculture as an urban land use into the Dar es Salaam master plan and beyond. Environ. Urban. 25, 541-558 (2013).

30. Halloran, A. \& Magid, J. The role of local government in promoting sustainable urban agriculture in Dar es Salaam and Copenhagen. Geogr. Tidsskr. 113, 121-132 (2013).

31. Hayhurst, R. D., Dietrich-O'connor, F., Hazen, S. \& Landman, K. Community-based research for food system policy development in the City of Guelph, Ontario. Local Environ. 18, 606-619 (2013).

32. Jarosz, L. The city in the country : Growing alternative food networks in Metropolitan areas. J. Rural Stud. 24, 231-244 (2008).

33. Jean, M. The role of farming in place-making processes of resettled refugees. Refugee Survey Quarterly 34, 46-69 (2015).

34. Karanja, N. et al. Strengthening capacity for sustainable livelihoods and food security through urban agriculture among HIV and AIDS affected households in Nakuru, Kenya. Int. J. Agric. Sustain. 8, 4053 (2010).

35. Koopmans, M. E., Keech, D., Sovová, L. \& Reed, M. Urban agriculture and place-making: Narratives about place and space in Ghent, Brno and Bristol. Morav. Geogr. Reports 25, 154-165 (2017).

36. Kulak, M., Graves, A. \& Chatterton, J. Reducing greenhouse gas emissions with urban agriculture: A Life Cycle Assessment perspective. Landsc. Urban Plan. 111, 68-78 (2013).

37. Lang, U. Cultivating the sustainable city: Urban agriculture policies and gardening projects in Minneapolis, Minnesota. Urban Geogr. 35, 477-485 (2014).

38. Lynch, K., Maconachie, R., Binns, T., Tengbe, P. \& Bangura, K. Meeting the urban challenge? Urban agriculture and food security in post-conflict Freetown, Sierra Leone. Appl. Geogr. 36, 31-39 (2013).

39. Martin, G., Clift, R. \& Christie, I. Urban cultivation and its contributions to sustainability: Nibbles of food but oodles of social capital. Sustain. 8, (2016).

40. Martin, W. \& Vold, L. Building capacity through urban agriculture: Report on the askîy project. Health Promotion and Chronic Disease Prevention in Canada 38, 29-35 (2018).

41. McLain, R. J., Hurley, P. T., Emery, M. R. \& Poe, M. R. Gathering 'wild' food in the city: rethinking the role of foraging in urban ecosystem planning and management. Local Environ. 19, 220-240 (2014).

42. Mendes, W., Balmer, K., Kaethler, T. \& Rhoads, A. Using land inventories to plan for urban agriculture: Experiences from Portland and Vancouver. J. Am. Plan. Assoc. 74, 435-449 (2008).

43. Milbourne, P. Everyday (in)justices and ordinary environmentalisms: Community gardening in disadvantaged urban neighbourhoods. Local Environment 17, 943-957 (2012).

44. Miller, W. M. UK allotments and urban food initiatives: (limited?) potential for reducing inequalities. Local Environ. 9839, 1-21 (2015).

45. Moragues-Faus, A. M. \& Morgan, K. Reframing the foodscape: the emergent world of urban food policy. Environ. Plan. A 47, 1558-1573 (2015).

46. Moschitz, H., Landert, J., Schader, C. \& Frick, R. From Urban Agriculture to Urban Food. Nature and Culture 13, 113-134 (2018).

47. Nemoto, E. H. \& Biazoti, A. R. Urban agriculture: How bottom-up initiatives are impacting space and policies in São Paulo. Futur. Food J. Food, Agric. Soc. 5, 21-34 (2017).

48. Newman, L. Extreme local food: Two case studies in assisted urban small plot intensive agriculture. Environments 36, 33-43 (2008).

49. Ofreneo, R. P. \& Hega, M. D. Womens solidarity economy initiatives to strengthen food security in response to disasters: Insights from two Philippine case studies. Disaster Prevention and Management 25, 168-182 (2016).

50. Olivier, D. W. \& Heinecken, L. The personal and social benefits of urban agriculture experienced by cultivators on the Cape Flats. Dev. South. Afr. 34, 168-181 (2017).

51. Orsini, F. et al. Exploring the production capacity of rooftop gardens (RTGs) in urban agriculture: the potential impact on food and nutrition security, biodiversity and other ecosystem services in the city of Bologna. Food Secur. 6, 781-792 (2014).

52. Passidomo, C. Whose right to (farm) the city? Race and food justice activism in post-Katrina New Orleans. Agric. Human Values 31, 385-396 (2014).

53. Passidomo, C. Community gardening and governance over urban nature in New Orleans's Lower Ninth Ward. Urban For. Urban Green. 19, 271-277 (2016).

54. Pawlikowska-Piechotka, A. Urban greens and sustainable land policy management (case study in Warsaw). Eur. Countrys. 4, 251-268 (2012). 
55. Perlman, S. E. et al. A Menu for Health: Changes to New York City School Food, 2001 to 2011. Journal of School Health 82, 484-491 (2012).

56. Petríková, D. \& Szuhová, J. Urban gardening to foster community places on brownfields. Journal of Urban Regeneration and Renewal 10, 132-137 (2017).

57. Pollard, G., Ward, J. \& Roetman, P. Typically diverse: The nature of urban agriculture in South Australia. Sustain. 10, (2018).

58. Poulsen, M. N. Cultivating citizenship, equity, and social inclusion? Putting civic agriculture into practice through urban farming. Agric. Human Values 34, 135-148 (2017).

59. Poulsen, M. N., Neff, R. A. \& Winch, P. J. The multifunctionality of urban farming: perceived benefits for neighbourhood improvement. Local Environ. 22, 1411-1427 (2017).

60. Psarikidou, K. \& Szerszynski, B. Growing the social: Alternative agrofood networks and social sustainability in the urban ethical foodscape. Sustain. Sci. Pract. Policy 8, 30-39 (2012).

61. Rego, L. F. G. Urban vegetable production for sustainability: The Riortas Project in the city of Rio de Janeiro, Brazil. Habitat Int. 44, 510-516 (2014).

62. Rekow, L. Fighting insecurity: eperiments in urban agriculture in the favelas of Rio de Janeiro. $F$. Actions Sci. Reports 8, 1-8 (2015).

63. Sacks, R., Yi, S. S. \& Nonas, C. Increasing access to fruits and vegetables: Perspectives from the New York City experience. Am. J. Public Health 105, e29-e37 (2015).

64. Sanjuan-Delmás, D. et al. Environmental assessment of an integrated rooftop greenhouse for food production in cities. J. Clean. Prod. 177, 326-337 (2018).

65. Sbicca, J. \& Myers, J. S. Food justice racial projects: fighting racial neoliberalism from the Bay to the Big Apple. Environ. Sociol. 3, 30-41 (2017).

66. Schwarz, K., Cutts, B. B., London, J. K. \& Cadenasso, M. L. Growing gardens in Shrinking cities: A solution to the soil lead problem? Sustain. 8, (2016).

67. Shey, J. E. \& Belis, D. Building a municipal food policy regime in Minneapolis: Implications for urban climate governance. Environ. Plan. C Gov. Policy 31, 893-910 (2013).

68. Shi, Y., Cheng, C., Lei, P., Wen, T. \& Merrifield, C. Safe food, green food, good food: Chinese community supported agriculture and the rising middle class. Int. J. Agric. Sustain. 9, 551-558 (2011).

69. Simatele, D., Binns, T. \& Simatele, M. Sustaining livelihoods under a changing climate: The case of urban agriculture in Lusaka, Zambia. J. Environ. Plan. Manag. 55, 1175-1191 (2012).

70. Sonnino, R. Feeding the City: Towards a New Research and Planning Agenda. Int. Plan. Stud. 14, 425435 (2009).

71. Soulard, C. T. et al. Peri-urban agro-ecosystems in the Mediterranean: diversity, dynamics, and drivers. Reg. Environ. Chang. 18, 651-662 (2018).

72. St. Clair, R., Hardman, M., Armitage, R. P. \& Sherriff, G. The trouble with temporary: Impacts and pitfalls of a meanwhile community garden in Wythenshawe, South Manchester. Renewable Agriculture and Food Systems 1-10 (2017). doi:10.1017/S1742170517000291

73. Stanko, H. \& Naylor, L. Facilitating (?) urban agriculture in Philadelphia: sustainability narratives in the inequitable city. Local Environ. 23, 468-484 (2018).

74. Thornton, A. "The Lucky country"? A critical exploration of community gardens and city-community relations in Australian cities. Local Environ. 22, 969-985 (2017).

75. Toth, A., Rendall, S. \& Reitsma, F. Resilient food systems: a qualitative tool for measuring food resilience. Urban Ecosyst. 19, 19-43 (2016).

76. Tryba, A. Filling the void with food: Urban gardens as safe spaces and alternatives to vacant land. Research in Political Sociology 23, 93-110 (2015).

77. van der Jagt, A. P. N. et al. Cultivating nature-based solutions: The governance of communal urban gardens in the European Union. Environ. Res. 159, 264-275 (2017).

78. Viljoen, A. \& Bohn, K. Continuous Productive Urban Landscape: Essential Infraestructure and Edible Ornament. Open House Int. 34, 50-60 (2009).

79. Warshawsky, D. N. Civil society and urban food insecurity: Analyzing the roles of local food organizations in Johannesburg. Urban Geogr. 35, 109-132 (2014).

80. Wekerle, G. R. \& Classens, M. Food production in the city: (re)negotiating land, food and property. Local Environ. 20, 1175-1193 (2015).

81. White, J. T. \& Bunn, C. Growing in Glasgow: Innovative practices and emerging policy pathways for urban agriculture. Land use policy 68, 334-344 (2017).

82. Yang, Z., Cai, J. \& Sliuzas, R. Agro-tourism enterprises as a form of multi-functional urban agriculture for peri-urban development in China. Habitat Int. 34, 374-385 (2010). 


\section{Appendix 6}

List 2. Review inclusion criteria and questions

\section{Descriptive information}

\section{Article number}

\section{Name of the journal the article is published in}

\section{First author}

\section{Name of reviewer}

\section{Is the paper appropriate for review?}

Papers should describe food related activities in the urban environment. Also, the paper should contain some kind of case-study, describe an impact, change process or comparison to the 'conventional'. // Select only one option

- Include; Complete the entire form

- Exclude; Go to Question 6 and do not continue the review.

- In between/Discuss; Go to Question 6 and try to complete the survey. List your concerns/questions at the end of the survey.

\section{In case you marked 'Exclude' or 'Discuss' in Q5. Why was it not suitable for review?}

Select only one option

- I crossed out included in Q5.

- Doesn't meet criteria, but good to include in the conceptual framing of the paper (introduction or discussion).

- Doesn't describe a case/impact/change process.

- Describes a methodology to assess urban food initiatives and doesn't apply it to a case.

- About an urban initiative, but not really about food.

- About food initiative, but not really about urban.

○ Just completely off...

\section{Methods}

\section{Country in which study was conducted}

If multiple, list each on a new line. If many, just state region (e.g. Baltic region, Europe, Global South...)

\section{What spatial scale is used in the paper?}

Can tick more than one if appropriate. *Added after being mentioned a couple of times in the initial 15 reviews. But do make sure you check whether it does plays out in an urban setting, as that is still a bit unspecified from these codes. // Multiple choice
○ Urban
○ City
- City-region
○ Town
- Local
○ Regional

- Peri-urban

- Neighbourhood

- Community Garden

- Unspecified

o Other: 


\section{Type of data used to assess Urban Food Initiative?}

Select only one

- Qualitative

- Quantitative

- Mixed

o Other:

\section{Data collection methods}

Can tick more if appropriate. *Added after being mentioned a couple of times in the initial 15 reviews. / Multiple choice
- Case-study (1 case)
- Case-study ( 2 or more cases)
- Interviews
- Survey / questionnaire
$\circ \quad$ Focus group
○ Multi-stakeholder workshop
- Participant observation
- Participatory mapping
○ Existing database (e.g. census)

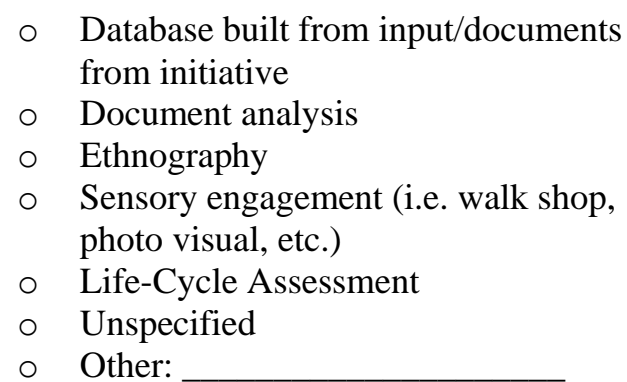

\section{Disciplinary grounding of the paper}

Dominant discipline(s) only. No more than 3. Consider (i) journal, (ii) whether stated in text, (iii) author affiliation, and (iv) literature cited. *Added after being mentioned a couple of times in the initial 15 reviews // Multiple choice

- Agricultural science / Agronomy

- Sociology

- Anthropology

- Human Geography

- Physical Geography

- Ecology

- Sustainability science

- Political ecology

- Economics

- Political economy

○ Urban/landscape planning

○ Tourism

- Architecture and Urban Design

- Psychology

○ Public administration

- (Public) Health and Nutrition

- Food Systems

- Environmental science

- Development Research

o Other: 


\section{Does the paper describe the impact the Urban Food Initiative made?}

As in, do they describe a change in a situation comparing 'before' and now? Can be both

negative, positive, or neutral. // Select only one option

- Yes, this impact is empirically supported (also see next question)

- Not really, but it explores the current situation and/or offers ideas and opportunities for improvement. i.e. more normative/conceptual (skip next question)

○ No (skip next question)

o Other:

\section{If the paper describes an impact, how is this 'measured'?}

As in, do they describe a change in the system over time? And if this is mentioned, what is the timescale involved? / Leave blank if you answered NO in previous question.

\section{Food system elements}

15. What do the activities of the initiative address?

I.e. What do they address? Can tick more than one if appropriate. // Multiple choice

- Social; the initiative creates or strengthens communities and social ties, and/or supports communication and cohesion

- Economic; the initiative creates jobs, supports local economic activity and/or promotes a viable business model

- Education; the initiative teaches food skills and promotes awareness about food, health, and/or the environment

- Environmental; the initiative is sustainable or beneficial to the environment in terms of nature, waste, energy, soil, water and air

- Health; the initiative provides affordable, nutritious, fresh and/or healthy food, and/or supports a positive public health agenda

- Infrastructure; the initiative contributes to the food infrastructure in terms of growing sites, community platforms, transportation and/or planning

- Liveability; the initiative creates interactive spaces, helps to reduce anti-social behaviour and/or provides urban amenities from cultural events and cafés to attractive and edible green space

- Governance; the initiative contributes to policy making and/or governing of institutions or important functions of the food system

- Social care; the initiative contributes to the care and/or therapy of people

- Poverty Reduction*; the initiative contributes to the reduction of poverty by making marginalized or vulnerable groups more food self-sufficient

- Unclear / None*

o Other:

\section{What type of actors are involved in the initiative?}

Tick one or more if appropriate. // Multiple Choice

- Farmers and fishermen (i.e. primary production)

$\circ$ Food processors/industry (e.g. processing, packaging, distribution)

- Retail (e.g. supermarkets)

- Small businesses (e.g. restaurants, farm shops, farmers markets)

- Social enterprises: company-like, but with social aims (e.g. food banks, food buying groups)

- Public actors (e.g. national, regional, city)

- Semi-public actors (e.g. social work, housing corporation etc.)

- Academia

$\circ$ Influencers (e.g. Think tanks, NGO's)

- Civil society actors (e.g. social movement, a 'community', volunteers)

- Consumers/eaters

- Marginalized groups (e.g. poor, elderly, migrants, etc.)

- Residents / Citizens 


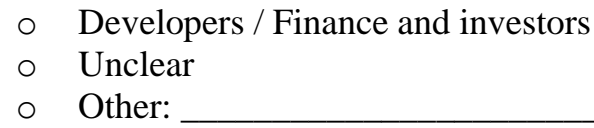

17. What food systems change processes does the initiative perform?

Tick one or more if appropriate. *Note: it could be that the initiative is more outcome focussed and none of these processes are very strong in the initiative. // Multiple Choice

- Integrated approach (combination of multiple food system domains)

- Participatory approaches (i.e. use of relevant stakeholders to design/plan/develop)

$\circ$ Strategic planning for the future (e.g. foresight)

- Adopt a city-region perspective (i.e. including the hinterlands)

$\circ \quad$ Creation of spatial synergies (i.e. linking different policy objectives)

$\circ$ Influencing of consumer decisions (e.g. nudging, marketing, awareness raising)

- Mobilisation of key actors (i.e. the targeting of a couple of actors that have the potential to 'tip' the system, like e.g. a number of big global retailers)

○ Unclear / None

o Other:

18. What food systems change outcomes do the initiatives processes result in?

Tick one or more if appropriate. *Note: it could be that the initiative is more process focussed and none of these outcomes are very strong in the initiative. // Multiple choice

○ Connection of flows/ efficient use of resources (e.g. cutting waste)

$\circ$ Changing diets

- Reduction of antimicrobial use

$\circ$ Fostering of resilience of production systems and the biosphere (strengthening biodiversity and multifunctionality)

- Reconnection of people to food (and through that the biosphere) for improved stewardship

○ Focus on food quality

- Enhancing of transparency between producers and consumers

- Increased competitiveness / economic opportunities

$\circ$ Increased equity in the food chain

- Food policy or new network

- Increased self-sufficiency for vulnerable groups

○ (Re)claiming space or land for the commons

- Unclear / None

o Other:

\section{Impact and type of initiative}

19. What was the main outcome of the study?

Or what recommendations do they make (especially interesting if this refers to any of the options of question 17 and 18)? Try to keep to a few sentences.

\section{Does the initiative fit any of these hypothesised categories?}

Tick one or more if appropriate. In case it doesn't fit, but you can also describe new categories. // Multiple choice

○ (Peri)-urban Agriculture

- Social/community gardening

- Educational food initiative

- Care farm initiative

- Short Food Supply Chain initiative

- Food policy initiative

- Food assistance or food justice initiative

- Restaurant/gastronomy-oriented initiative

- It does not fit any of these categories

o Other: 


\section{Comments}

21. Comments about questions in the survey

Notes about specific questions can be put here, citing the question number.

22. In case you selected 'Discuss' in Q5, list your concerns and questions here.

23. Lastly, was the paper enjoyable to read?

Select only one option

○ Yes!

$\circ \quad$ Kind of...

- No, was difficult to get through 